Loyalty for Sale? Military Spending and Coups d'Etat

Gabriel Leon

February 2012

CWPE 1209 


\title{
Loyalty for Sale?
}

\section{Military Spending and Coups d'Etat}

\author{
Gabriel Leon* \\ University of Cambridge \\ This version: February 1, 2012.
}

\begin{abstract}
Coups d'etat continue to be common around the world, often leading to changes in leaders and institutions. We examine the relationship between military spending and coups and find that (i) successful coups increase military spending by more than failed attempts, and (ii) coups are more likely when military spending as a share of GDP is relatively low. Our identification strategy exploits the conditional independence between a coup's outcome and the change in military spending that follows it. We interpret this as evidence that the military may stage coups in order to increase its funding, and rule out several alternative mechanisms.
\end{abstract}

Keywords: coups, income, conflict, military spending, political economy.

JEL: H56, N40, D72, O17.

*Address: Faculty of Economics, University of Cambridge, Sidgwick Avenue, Cambridge CB3 9DD. Email: gj138@cam.ac.uk. Website: http://www.caths.cam.ac.uk/personal/gleon. I wish to thank Oriana Bandiera, Tim Besley, Chris Bliss, Clare Leaver, Gilat Levy, Leandro de Maghallanes, Torsten Persson, Francis Teal and the participants at the Berkeley Center for Political Economy Workshop 2011, for their helpful comments. I kindly acknowledge the financial support of the ESRC. 


\section{Introduction}

There is a growing consensus that political institutions and leadership matter for economic outcomes. ${ }^{1}$ Political transitions and leadership changes often take place through coups d'etat, but coups remain a little understood political phenomenon. With the exception of Londregan and Poole (1990), who show that low income per capita is correlated with a higher incidence of coups, the relationship between economic variables and coups has not been explored in detail.

In this paper we examine the relationship between military spending and coups. ${ }^{2}$ Political scientists have long argued that low military spending may trigger coups, as in the case of the 1966 coup in Ghana. To justify his participation in this coup, Colonel A. A. Afrifa claimed that "the army was rendered incapable, ill-equipped, [having] virtually been reduced to a rabble. By Christmas 1965 a number of our troops were without equipment and clothing, things essential for the pride, morale and efficiency of the soldier... It was shameful to see a Ghanaian soldier in a tattered and ragged uniform, sometimes without boots during his training period" (Afrifa, 1966). Furthermore, governments can use military spending to 'buy off' the military and keep it from staging coups. Nordlinger (1977) cites the example of President Romulo Betancourt in Venezuela, who "managed to serve out his entire constitutional term of office - the first time this had occurred in that country's military-dominated history - by providing the officers with the best salaries, rapid promotions, and a generous allotment of fringe benefits" (p.70). Recent economic models of the military by Acemoglu, Ticchi and Vindigni (2010), Besley and Robinson (2010) and Leon (2009) assume that the military can be bought off through greater military spending. ${ }^{3}$

We establish two empirical facts: (i) successful coups result in greater increases in military

\footnotetext{
${ }^{1}$ For example, see the seminal papers by Acemoglu, Johnson and Robinson (2001) and Jones and Olken (2005).

${ }^{2}$ We define coups as attempts to overthrow the government by a group within the military, which rules out overthrows in which the military does not participate. As it will become clear later, coups are quite distinct from civil wars.

${ }^{3}$ In theory, military spending could affect a coup's likelihood of success through its impact on its fighting capability. We later show empirical evidence that suggests that this is not the case.
} 
spending than failed coups, and (ii) coups are more likely when military spending as a share of GDP is relatively low. For this we use data for 153 countries for the period 1963-1999, which includes coups, information on whether they succeeded or failed, military spending, and other country level variables. The coup data comes from Belkin and Schofer (2003), which is one of several coup datasets available, and the best suited for our purposes. The data on military spending and on the size of the military comes from the U.S. Arms Control and Disarmament Agency, which is widely regarded as one of the most complete sources of historical military spending data and the best in terms of within country consistency.

The main difficulty in studying coups empirically is that the variables that determine whether coups happen, including military spending, can also be affected by coups. This will be the case, for example, if the government fears that a coup is about to take place and adjusts military spending in an attempt to prevent it. To deal with this endogeneity problem we initially limit our attention to cases in which coups occurred, comparing the impact of success and failure on military spending; this allows us to establish empirical fact (i). This approach is analogous to treating the outcome of a coup as a natural experiment, creating a control group of failed coups and a treatment group of successful coups, and is similar to the strategy used by Jones and Olken (2009) to study the impact of assassinations. ${ }^{4}$ Our identifying assumption is that the outcome of a coup is independent from the post-coup change in military spending, conditional on all relevant observable variables. This allows us to use difference in differences estimation to test for whether successful coups have a different impact on military spending than failed coups. We check for the validity of our identification assumption in several ways. First, we plot the trends in military spending around the time of a coup, for both successful and failed coups, and see that the trends are quite similar. We then divide the coups into two groups, successful and failed, and compare the group sample means for each variable evaluated on the year before the coup. We find no difference except

\footnotetext{
${ }^{4}$ As part of their seminal research on leadership, Jones and Olken (2009) use the outcome of assassination attempts to estimate the impact of changes in leadership on institutions and war. They restrict their sample to cases in which the weapon was used, so that the outcome of the assassination attempt can be taken as random.
} 
that mean average military spending (as a fraction of GDP) before a successful coup is lower than that before a failed coup, suggesting that greater military spending does not improve a coup's probability of success. We also regress a coup's outcome on a number of controls evaluated the year before the coup, to see whether any of these variables is a good predictor of a coup's outcome; none of these variables predict the success or failure of coup attempts.

We compare military spending before and after each coup, and find that successful and failed coups differ significantly in their impact on military spending, with successful coups leading to changes in military spending that are about $25 \%$ greater than the changes following failed coups. We find that the effect is entirely due to changes following successful coups against non-democracies; changes in military spending following a successful coup against democracy are indistinguishable from those following a failed coup. To further deal with the concern that unobservables may affect both coup outcome and the changes in military spending that follow a coup, we re-run our regressions using only coups that resulted in casualties. Our reasoning is that these are coups where the outcome is likely to have been uncertain ex-ante, and so where systematic differences in unobservables are less likely. Our results are stronger when we focus on this reduced sample. ${ }^{5}$

In order to establish fact (ii) we estimate a panel specification that looks at whether military spending is correlated with the incidence of coups. ${ }^{6}$ We use fixed effects to control for time-invariant country characteristics (e.g. institutions) that can affect income, military spending and coups. We find a negative and significant relationship between military spending and coups: within a country, years with lower military spending are followed by years when the probability of a coup is higher. For the average country-period pair, we find that increasing military spending as a share of GDP by one percentage point leads to a 1.5 percentage point decline in the probability of a coup in that 5 year period (where the mean

\footnotetext{
${ }^{5}$ We look at a number of other variables one and three years after a coup, and check whether the means differ significantly depending on the coup's outcome. We find no significant difference across success and failure except in institutions. This suggests that other policies and outcomes do not change differentially depending on a coup's outcome.

${ }^{6}$ This section focuses on correlations (rather than causal statements) and so the conclusions are more tentative.
} 
is $18 \%$ ). To put this into context, a one standard deviation increase in military spending lowers the probability of a coup in the following five years in the average country-period pair from $18 \%$ to $8 \% .^{7}$

Our results are consistent with the view that military spending matters for coups: coups are more likely when military spending is low relative to a country's average, and successful coups are followed by larger increases in military spending than failed coups. We argue that one plausible explanation for this is that coups against non-democracies are often staged by militaries that wish to increase military spending, while that is not the case for coups against democracy. These findings also lend support to the argument that the military may overlook other reasons to stage a coup when it is being paid enough. Nordlinger (1977) claims that this is exactly what happened in Venezuela, where generous military allowances funded by oil revenue allowed Romulo Betancourt to avoid a coup "despite the adoption of expensive agrarian reforms and development programs" (p.70). Conversely, low military spending may lead to a coup regardless of whether other causes are present. This is consistent with the experience of Peru between 1912 and 1964, when "every civilian government that reduced the proportion of the national budget assigned to the Peruvian military was overthrown, and this despite the continual increases in the absolute size of military expenditures" (p.67).

There are a number of alternative mechanisms that could connect military spending and coups, and our findings allow us to refute a number of them. Two of these alternatives, which would also undermine our identification strategy, are that (a) the coup plotter's talent or ambition impacts on the success but also on changes in military spending, and that (b) there might be expected shocks to income that affect both a coup's likelihood of success and military spending. We consider a number of other alternatives: (c) successful coups are followed by more repression and this requires increased military spending, (d) the results

\footnotetext{
${ }^{7}$ We also find that income measures have a significant negative relationship with coups when no fixed effects are included, which is consistent with the literature (e.g. Londregan and Poole, 1990). However, this result vanishes when we introduce fixed effects, suggesting that income per capita may be acting as a proxy for unobserved country-specific and time-invariant factors like institutions. The coefficient for the income measures is positive but insignificant, so that there is no evidence linking income to the likelihood of coups.
} 
are driven by decreases in military spending following failed coups (e.g. the government punishes the military), (e) the military is opportunistic so that military spending goes up after a successful coup even if that was not the motivation for it, and (f) low military spending may be a reflection of a small military that can more easily coordinate. We show that none of these alternatives is consistent with both of our empirical findings.

This paper contributes to the literature on political transitions that originates with the seminal work of Acemoglu and Robinson (2001, 2005). Its main contribution is to study coups empirically, and it is closely related to a small but growing theoretical literature on the military and its role in political transitions. Acemoglu, Ticchi and Vindigni (2010) show the circumstances under which the military may rebel against the elite, stage a coup, and establish a military dictatorship. In their model, an elite may pay the military high wages to avoid coups. Besley and Robinson (2010) look at the optimal size of the military, and conclude that a government may choose to pay it an efficiency wage in order to avoid coups. Leon (2009) looks at the relationship between war, coups and institutions, and shows that there is a non-monotonic relationship between the frequency of war and the likelihood of a coup. Our empirical findings lend support to a key feature of these models: that the military may stage coups if it is not properly funded.

This paper also contributes to the literature on the economic causes and consequences of coups, a topic that has received much less attention than the economic causes of civil conflict. $^{8}$ The seminal papers in this literature are by Londregan and Poole $(1990,1996)$. Londregan and Poole (1990) estimates a simultaneous equation model using time series methods. It finds that income per capita, economic growth and coups in the recent past are important predictors of future coup attempts. Our paper differs primarily in its focus

\footnotetext{
${ }^{8}$ The literature on the economic causes of civil wars is extensive. For example, Collier and Hoeffler (1998, 2004) and Fearon and Laitin (2003) found a correlation between economic circumstances and civil wars, while Miguel et al. (2004) showed that income shocks could cause civil war. More recently, Djankov and ReynalQuerol (2008) show that these correlations are spurious; while Ciccone (2011) shows that accounting for the persistence of shocks in Miguel et al. (2004) reverses the latter's results. Brueckner and Ciccone (2009) show that commodity price shocks and recessions in trading partners can lead to civil conflict; Djankov and Reynal-Querol (2007) find that economic institutions are key determinants of civil wars.
} 
on military spending and the use of a new identification strategy to deal directly with the endogeneity problem. Collier and Hoeffler (2005) also find that income measures impact on the likelihood of coups in Africa, while Collier and Hoeffler (2007) find that the risk of a coup d'etat has a non-monotonic impact on military spending. There is a literature in political science that is concerned with the military; classic studies include Huntington (1957), Finer (1962), Luttwak (1969) and Nordlinger (1977). The first agency model of the military is due to Feaver (2003), who used it to explain civil-military relations in the United States. Belkin and Schofer (2003) construct a coup risk measure based on past coups, the strength of civil society, and regime legitimacy.

Our paper shows that coups against non-democracies may be motivated by greed, while coups against democracies appear to be driven by other factors; in doing so it contributes to the literature that seeks to understand the differences between political regimes. Our findings are consistent with those of the cross-country study by Mulligan et al. (2004), which shows that autocracies have higher military spending than democracies. It is also related to the recent papers by Besley and Kudamatsu (2007) and Acemoglu et al. (2008), which show that economic outcomes may differ across political regimes.

The rest of this paper proceeds as follows: section 2 describes our data, while section 3 establishes empirical fact (i). Section 4 establishes empirical fact (ii), while section 5 discusses the possible mechanisms giving rise to our empirical findings. Section 6 concludes.

\section{Data on Coups and Military Spending}

We use a dataset with observations for 153 countries for the period 1963-1999, which includes coups, their outcome, military spending, and other country level variables. The coup data comes from Belkin and Schofer (2003). There are a number of different coup datasets, and they differ across two key dimensions: on how they define coups, and on whether they report failed as well as successful coups. Given our interest in military spending, we want our 
definition of coups to be limited to cases in which the military is a key actor. This includes most coups, and leaves out insurrections and coups by civilians, which are altogether very different events. Belkin-Schofer proves the most useful because it defines coups as actions aimed at removing the 'regime' by a 'small military coalition.' Naturally, we want a dataset that includes both successes and failures, as Belkin-Schofer does. Furthermore, the BelkinSchofer dataset is quite comprehensive in terms of country and time coverage.

To construct their data, Belkin and Schofer (2003) compiled a list of coups from a number of academic articles, and complemented it with data from Keesing's Contemporary Archives. They checked the accuracy of this list by consulting regional experts and resolving conflicting cases with information from the New York Times and Foreign Broadcast Information Service. More details can be found in Belkin and Schofer (2003). We then construct the data on the outcome of coups (i.e. whether they succeeded or failed), for those coups in Belkin and Schofer (2003), by using data from Banks (2001) and Powell and Thyne (2010). In a small number of cases the outcome in Banks (2001) differed from that in Powell and Thyne (2011); in these instances we checked the outcome by looking at online news sources.

We have coup information for 4,760 country-years, with a total of 306 coups taking place in 247 country-years, as shown in Table 1. That is, coups occur in slightly more than 5\% of our country-years. Table 2 shows that information on whether a coup succeeded or failed is available for 232 coups, and that in almost exactly half the cases the coup succeeded. Although coups are infrequent, Table 3 shows that close to half of the 153 countries in the dataset experienced at least one coup between 1963 and 1999. Table 4 shows the average number of coups by country-year, separated by region and decade. The differences across regions are stark, with countries in Sub-Saharan Africa and Latin America experiencing the most coups. Coups have become much less common worldwide: from the 1960s to the 1990s, coups in Sub-Saharan Africa have halved while those in Latin America have decreased by more than two thirds.

We use data on political regimes from Cheibub, Gandhi and Vreeland (2010), which is 
rooted in the datasets in Alvarez et al. (1996) and Przeworski et al. (2000). Like them, Cheibub, Gandhi and Vreeland (2010) classify regimes into just two categories: democracy and dictatorship. We use two of their variables: 'democracy', which equals 1 if the country is democratic and 0 otherwise; and 'military regime', which equals 1 if the country is ruled by the military and 0 otherwise. Table 5 shows that most coups are staged against nondemocracies. However, whether a coup succeeds or fails appears to be unrelated to whether the target regime is democratic. Perhaps not surprisingly, the vast majority of successful coups lead to non-democratic regimes, while most failed coups result in the regime type remaining unchanged.

The data on military spending and on the size of the military was collected from the "World Military Expenditures and Arms Transfers" reports produced by the U.S. Arms Control and Disarmament Agency. These are widely regarded as one of the most complete sources of historical military spending data. Conversations with researchers at both the International Institute for Strategic Studies (IISS) and the Stockholm International Peace Research Institute (SIPRI), the main other sources for data on military spending, suggested that the data from the U.S. Arms Control and Disarmament Agency was the best suited for a study that looks at changes over time. The reason is that this data was collected under the supervision of the same individual from the early 1960s to the early 1990s, ensuring some degree of within country consistency over time.

Table 6 shows average military spending as a percentage of GDP (out of 100) by countryyear, separated by region and decade. Surprisingly, mean military spending in Sub-Saharan Africa and Latin America has always been relatively low compared to that in wealthier regions like Europe and North America. Furthermore, different regions seem to follow different trends: spending in both Latin America and Sub-Saharan Africa seems to have peaked in the 1980s, while other regions have experienced declines since the 1970s.

We use data on GDP, population, and the allocation of countries to regions from the World Bank Development Indicators (2009). Our data on political instability comes from 
Banks (2001); we use the 'weighted conflict index' variable, which is listed by Powell (2010) as a good predictor of coup outcomes. We use data on casualties resulting from coups from Marshall and Marshall (2010), corrected for missing values using news data we collected from the New York Times Archive. For more details on all variables please see the appendix. Summary statistics for all key variables are shown in Table 7.

\section{Coup Outcome and Military Spending}

\subsection{Specification}

In this section we establish our first empirical finding: (i) successful coups increase military spending by more than failed attempts. In order to test how successful coups impact on military spending we need to take into account that military spending might be trending. We need to distinguish the true impact of experiencing a successful coup from the trend, and it is possible that trends differ across regions and between time periods with coups and those without. A natural way to proceed is to follow the approach used by Jones and Olken (2009) to examine the impact of assassinations on institutions and war. We limit our attention to cases where coups took place, and compare instances in which the coups succeeded with instances in which they failed. We use a difference in differences specification, where our natural experiment is experiencing a successful coup; treated units are those where a successful coup took place, while the controls are those in which the coup failed. This allows us to estimate an average treatment effect: the average impact on military spending from experiencing a successful coup instead of a failed one.

This approach eliminates the problem caused by the possible endogeneity of coup attempts. However, for us to correctly estimate the impact of successful coups on military spending, the grouping variable (in our case whether the coup succeeds or fails), needs to be conditionally independent from the variable of interest (military spending after the coup). This requires that we control for selection into and out of the treatment group, so that once 
we have controlled for the factors that affect a coup's probability of success, we can take the outcome of a coup to be independent from the changes in military spending that follow it. This is the 'common trends' condition that allows us to use failed coups as counterfactuals: if one of the successful coups had instead failed, military spending would have changed as in the control group of failed coups. Figure 1 shows the trends in military spending for successful and failed coups, both before and after the event. The trends are constructed by fitting lines through the annual average military spending for each group (without controlling for other observables). The figure shows military spending follows a similar trend for both successful and failed coups. This is true both before and after a coup, the main difference being that in the case of successful coups the trend is shifted upward.

In the next section we present a number of empirical tests that provide further support for the common trends assumption. More generally, for the common trends condition to be valid it must be that assignment, once we control for observables, is independent from the change in military spending following a coup. There are a large number of observables that could impact on whether coups succeed or fail. In a recent study, Powell (2010) considers these variables and concludes that a coup's probability of success is significantly related to political instability, regime type, soldier quality, the quantity of military personnel, and whether the regime is military. These are measured by the Banks (2001) 'weighted conflict index' variable, whether the regime is democratic, military spending per soldier, the size of the military and whether the regime is military, respectively. We control for all of these variables and argue that, conditional on these controls, success is independent of the changes in military spending brought about by the coup. This requires that whether a coup attempt succeeds cannot depend on unobservables that also impact on the change in military spending following the coup. Possible unobservables include the coup plotter's talent, which might affect whether the coup succeeds but also the plotter's ability to increase military spending afterwards; or expected shocks (e.g. to income) that may affect the coup's outcome but also future military spending. However, it is unlikely that ability plays a role in the plotter 
being able or willing to increase military spending after a successful coup, and we later show empirical evidence that helps rule out this possibility. We also find evidence suggesting that expected shocks are unlikely to be driving the outcome of coups. There may be other unobservables, of course, and to deal with this possibility we repeat our estimation using only coups that resulted in casualties. In these coups the outcome is more likely to have been ex-ante uncertain, and so success is more plausibly unconditionally independent from changes in military spending.

Our main specification is:

$$
m_{i, t}=\alpha+\beta_{1} c_{i, t}+\beta_{2} s_{i}+\beta_{3} c_{i, t} s_{i}+\beta_{4} x_{i, t}+u_{i, t}
$$

where $m$ is military spending, $i$ refers to a specific coup, and $t$ indexes time. The year of a coup is $t=0$, with $t<0$ counting the years before the coup, and $t>0$ counting the years after. The binary variable $c_{i, t}$ equals 0 before coup $i$ and 1 after; the variable $s_{i}$ equals 0 if coup $i$ failed, and 1 if it succeeded. The coefficient $\beta_{1}$ captures the impact of failed coups on military spending, while $\beta_{1}+\beta_{3}$ measures the impact of successful coups on military spending. By looking at whether $\beta_{3}$ differs from zero we can establish whether successful coups have an impact on military spending that differs significantly from that of failed coups.

We expect that success leads to greater increases, so that $\beta_{3}>0$, where $\beta_{3}$ is the average treatment effect:

$$
\beta_{3}=E[m \mid \text { success, } x]-E[m \mid \text { failure }, x],
$$

where the identification assumption is that a coup's outcome is uncorrelated with the error $u_{i, t}$ in (1); that is

$$
E\left[u_{i t} \mid x_{i t}, \text { success }\right]=E\left[u_{i t} \mid x_{i t}, \text { failure }\right]=0 \text {. }
$$

The implication of this assumption is that once we include all relevant controls, coups that succeed would have led to the same expected change in military spending, had they instead failed, as coups that actually failed. The controls $x_{i, t}$ include the size of the military the year 
before the coup, as this may impact on the coup's outcome; income per capita (or income and population), which can affect both military spending and the outcome of a coup; and regional and decade fixed effects, as we know that there is substantial heterogeneity across regions and over time (where the number of observations precludes the estimation of country or year effects). We also need to control for regime type, as it potentially affects both the coup outcome and military spending. We do this by including a dummy for whether the regime the year before the coup was democratic, and a dummy for whether the government was in the hands of the military. ${ }^{9}$

\subsection{Results}

Our identification strategy requires that we compare spending before and after coups, which becomes problematic when coups occur in consecutive years. We drop these coups, which reduces our sample to 157 coups, but in the appendix we report results for a second approach in which we group coups that take place in consecutive years into a single event, and compare spending before the first of these coups with spending after the last of these coups.

We first test for the extent to which the observable variables cited as determinants of a coup's outcome have a clear impact on the outcome of coups. Table 8 shows sample means for a number of variables, evaluated for country-years in the year prior to a coup. We separate the observations based on the coup attempt's outcome, and test for whether the difference between the sample means is significant. It is striking that most of these variables have the same mean across groups. The one exception is military spending as a percentage of GDP, where the mean is lower for successful coups. The fact that militaries with lower spending are more likely to succeed suggests that spending is unlikely to affect a military's ability to stage successful coups. However, we should interpret this result with caution because it does not arise when military spending is measured in levels, and it is based on a cross-country average.

\footnotetext{
${ }^{9}$ Not all non-democracies are military regimes; for example, there are a large number of civilian autocracies.
} 
We also look at whether these variables can predict the outcome of a coup. We do this by estimating the following specification:

$$
s_{i}=\alpha+\gamma_{1} m_{i,-1}+\gamma_{2} x_{i,-1}+\varepsilon_{i, 0} .
$$

The idea is to see whether these variables, either on their own or jointly, can help predict the outcome of a coup. Table 9 presents the results. In columns 1-4 we show estimates of a linear probability model where the dependent variable is the binary coup outcome: 1 if the coup succeeded, and 0 otherwise. On the right hand side we include a measure of military spending, a number of controls, and region and decade fixed effects. We find that all of the coefficients are insignificant, with the exception of the log of income per capita in column 1. In all four columns we can easily reject the null hypothesis that the coefficients (excluding the fixed effects) are jointly significant. Again, we should note that military spending appears to have no impact on a coup's outcome. In order to account for the binary nature of the dependent variable, in columns 5-8 of Table 9 we show the results of logit regressions. We again find that none of the coefficients is significant with the exception of the log of income per capita in column 5. An F-test cannot reject the null hypothesis of all coefficients (excluding the fixed effects) being jointly equal to zero. These results suggest that a coup's outcome is exogenous with respect to these observable variables evaluated the year before the coup takes place. ${ }^{10}$ Although in what follows we control for these variables, there is no compelling evidence that they impact on the outcome of a coup.

Table 10 presents our main results on how a coup's outcome impacts on military spending. Columns 1-3 use military spending as a fraction of GDP, measured between 0 and 100, as the dependent variable. In all three cases the post-coup dummy $\beta_{1}$, which captures the impact of failed coups on military spending, is negative; the success dummy $\beta_{2}$, which shows

\footnotetext{
${ }^{10}$ This is somewhat at odds with the results in Powell (2010), who found these variables to be the only significant determinants of a coup's outcome. Powell's (2010) results use a different sample of coups, different definitions for some of the variables, and are based on Heckman Probit estimation; it is unclear whether they are robust to using alternative specifications or estimation techniques.
} 
the difference between the success and failure groups before the coup, is also negative. The impact of successful coups, measured by $\beta_{1}+\beta_{3}$, is positive but insignificant. However, the only effect we can identify is the interaction captured by $\beta_{3}$, which is the difference between the impact of successful and failed coups on military spending. In all cases it is positive and significant. The estimated difference in the first column is 1.4 percentage points; in columns 2 and 3 it is around 0.8 of a percentage point. This difference is quite large, considering that mean military spending in the year prior to a coup for countries where the coup succeeds is 3.05 ; this difference is over $25 \%$ of the initial value of military spending. Interestingly, the political variables 'democracy', 'military regime' and 'instability' are largely insignificant.

In columns 4-6 we repeat the regressions but use the log of military spending in levels as the dependent variable. We do this because the effect we found could be generated mechanically if successful coups lead to greater drops in GDP than failed attempts, thus resulting in a larger increase in military spending as a fraction of GDP. The new coefficients have the same signs as before, and are significant except in column 4 where controls and fixed effects are excluded. The impact is a $7.7 \%$ increase in military spending from success in column 4 , and over $25 \%$ in columns 5 and 6 . The magnitude of this effect is substantial, and similar in size to that estimated in columns 2 and 3. Overall, Table 10 shows that successful coups lead to changes in military spending that are greater than those following failed coups. ${ }^{11}$

Table 11 shows the results when we restrict our sample to coup attempts that resulted in casualties. All coups with non-zero casualty counts are included; we do not make use of the number of deaths because sometimes they are reported as approximations (e.g. "4050 dead") and sometimes no numbers are given (e.g. "heavy casualties were reported"). The coefficients are of a larger magnitude, and their signs are the same as before, with the

\footnotetext{
${ }^{11}$ In table A1 we show the results when we include coups in consecutive years. We count these coups as one event, so that the pre-coup year is the one before the first coup, and the post-coup year is the first after the last coup. If any of these coups succeeded we treat the event as successful. We also include a control variable equal to the number of years included in the event. Again we find a significant difference in the change in military spending depending on a coup's outcome.
} 
difference in the change in military spending across successful and failed coups still being significant. ${ }^{12}$

Table 12 and 13 repeat these estimations but focusing only on coups against democracies and non-democracies, respectively. As table 12 makes clear, coups against democracies do not lead to greater increases in military spending after success; the coefficients are small and insignificant. ${ }^{13}$ In table 13, on the other hand, the result is still present, and the coefficients are now larger. This suggests that the impact we found in Table 10 is driven by coups against non-democracies and is evidence of an important difference between these two types of regime: although it seems plausible that coups may be staged against non-democracies in order to increase military spending, this does not appear to be the case for democracies.

Table 14 compares the means of the main control variables the year before and the year after the coup, separating successful from failed coups. Only the institutional measures show significant differences in political regimes, something that is not surprising given that most successful coups lead to non-democratic regimes. The means for all other variables are not significantly different, suggesting that other policies are not affected by the coup's outcome. ${ }^{14}$

\footnotetext{
${ }^{12}$ In table A2, columns 1-4 repeat the estimation but include data from three years before and three years after a coup. This enables us to better estimate the trends in the data, but the number of coups goes down to 80. (We cluster the standard errors to correct for serial autocorrelation, as suggested in Bertrand, Duflo and Mullanaithan (2004).) Once again, we find that successful coups lead to changes in military spending that are greater than the changes following failed coups. These results are significant in columns 1,2 and 4 (and the p-value for the interaction term in column 3 is 0.11). The estimated magnitudes are similar: roughly 1 percentage point in columns 1 and 2 and over $30 \%$ in columns 3 and 4 . This suggests that little is lost by using only data from the year before and the year after a coup. In columns 5-8 we allow for regional time trends to check whether our results are due to us picking up the impact of different regional trends, rather than that of successful coups. We find that our estimates remain largely unchanged once we include regional time trends.

${ }^{13}$ We should note, however, that the number of observations is relatively small.

${ }^{14}$ Table A3 replicates this table but looking at the means 3 years before and 3 years after a coup.
} 


\section{Military Spending and Coup Attempts}

\subsection{Specification}

In this section we establish our second empirical finding: coup attempts are more likely when military spending as a share of GDP is relatively low. If our hypothesis is correct and coups are staged in order to increase military spending, we would expect that a country is more likely to experience a coup when it sets its military spending relatively low. This suggests that a panel specification with fixed effects would be a natural framework to use, and we regress a measure of coups on military spending, income and a number of control variables:

$$
\operatorname{coup}_{i t}=\alpha+\beta_{1} \operatorname{milexp}_{i t-1}+\beta_{2} \text { income }_{i t-1}+\beta_{3} \text { controls }_{i t-1}+\eta_{t}+\psi_{i}+\varepsilon_{i t}
$$

where $i$ indexes the country and $t$ indexes time, $\eta_{t}$ are year dummies, $\psi_{i}$ are country dummies and $\varepsilon_{i t}$ is the error term. The variable $\operatorname{coup}_{i t}$ measures whether there is a coup attempt (regardless or whether it succeeded or failed) in a five year period; it equals 1 if there was at least one coup in the 5 year period, and 0 otherwise. There are seven periods: 19651969, 1970-1974, 1975-1979, 1980-1984, 1985-1989, 1990-1994, 1995-1999. The right hand side variables are all evaluated in the year before the five year interval begins, that is: 1964, 1969, 1974, 1979, 1984, 1989, $1994 .{ }^{15}$ Military spending is measured as a percentage of GDP, and income is GDP per capita or GDP and population. We control for the size of the military, whether the regime is democratic, whether it is military, and for instability. This specification is based on a growth regression and is in the spirit of that used by Londregan and Poole (1990).

We include country fixed effects to take account of the possible omitted variable bias affecting the estimated relationship between coups, income and military spending. One likely source of bias is the omission of country-specific characteristics (e.g. institutions) that

\footnotetext{
${ }^{15}$ The results are similar if we shift the start of the five year periods one year backwards or forward. The year dummies are for these seven years.
} 
may be driving coups and military spending in opposite directions. ${ }^{16}$ In recent years new evidence has come to light suggesting that existing cross-country correlations disappear once fixed effects are included. ${ }^{17}$ The fixed effects transformation implies that we identify the effect of income and military spending on coups from within country variation only. We lag the right hand side variables to reduce the possibility of simultaneity, as it is less likely that coups in a given five year period affect military spending and other variables a year before the start of that period. Regardless, these estimates should be interpreted as correlations and not as causal relationships.

Table 15 shows the summary statistics for the data used in this section. The coups variable, which measures whether there was a coup or not in the five year period, has a mean of 0.18 , indicating that in roughly $18 \%$ of the 5 year intervals there was at least one coup. The other variables are measured annually, although only in years before the 5 year periods begin, and the means and standard deviations are similar to those in the complete dataset.

\subsection{Results}

In Table 16 we show the panel results for specification (3). The first two columns exclude the country fixed effects, and we find that the coefficients on military spending and the income measures (GDP in column 1 and GDP per capita in column 2) are negative and significant. The size of the military is only significant in column 2 , while the coefficient on military regime is positive and significant in both columns. Finally, instability is positive and significant in both columns. These results are consistent with Londregan and Poole (1990, 1996), who showed that higher income per capita is correlated with a lower probability of a coup.

\footnotetext{
${ }^{16}$ Acemoglu, Johnson and Robinson (2001) emphasise that institutions remain unchanged through centuries.

${ }^{17}$ Djankov and Reynal-Querol (2008) show that poverty is not correlated with civil conflict once country fixed effects are included; Acemoglu et al. (2008) show that fixed effects eliminate the observed cross-country correlation between income and democracy.
} 
In columns 3 and 4 we introduce country fixed effects. ${ }^{18}$ Military spending is still negative but the magnitude is greater, and the results are significant at the $1 \%$ level. ${ }^{19}$ This shows that greater military spending in the year before the start of a five year period is associated with a lower probability of a coup attempt in that period. Specifically, a one percentage point increase in military spending at the mean (from 4.66 to 5.66) results in a small reduction in the probability of at least one coup in the next five years, from $18 \%$ to $16.5 \%$. However, the result is substantial when we consider a one standard deviation change in military spending (from 4.66 to 11.44 ), which would imply a decrease from $18 \%$ to $8 \%$. Of course, a one standard deviation increase in this case is substantial, but the large differences in military spending that we observe in practice can explain an important part of the differences in the incidence of coups. In columns (5) and (6) we run conditional logit regressions to check for the robustness of the result, although in this case we lose about half the countries in the dataset since they do not experience any coups in the sample period.

A surprising result is that income has no impact on coups once fixed effects are included. ${ }^{20}$ It is also interesting that the size of the military and the type of regime (whether democratic or whether a military dictatorship) lose their predictive power once country fixed effects are included. Only instability remains significant, with its coefficient largely unchanged. ${ }^{21}$

These results are robust to changing the years used to construct the five year intervals (i.e. starting in 1964 or 1966), and to including a lagged dependent variable, in this case coups in the preceding five year period. ${ }^{22}$ In Table 17 we repeat the estimation but separate

\footnotetext{
${ }^{18}$ In both cases an F-test rejects the null hypothesis that all fixed effects are equal, suggesting that they need to be included.

${ }^{19}$ This is reassuring, considering that it is common for cross-country results to vanish once fixed effects are introduced.

${ }^{20}$ This would seem to indicate that income levels are not relevant once we control for country-specific characteristics, and that the Londregan and Poole (1990) result might not be robust. We should note, however, that these statements should be interpreted with caution because annual GDP measurements exhibit a substantial amount of error.

${ }^{21}$ There is the concern, however, that this variable is mechanically related to coups. The results are largely unchanged when this variable is removed.

${ }^{22}$ The coefficients are insignificant and have a negligible impact on our estimates, while the inclusion of a lagged dependent variable introduces a number of econometric complications. For example, the 'Nickell bias' becomes a problem. Nickell (1982) showed that a lagged dependent variable causes the parameter estimates to be inconsistent when fixed effects are included.
} 
the impact of military spending depending on whether the country is democratic or not the year before the 5 year period begins. We find that the coefficient on military spending in the case of non-democracy remains as before, and that the difference between democracy and non-democracy is small and insignificant. Again income does not appear to have an impact on the incidence of coups. In summary, the evidence in this section shows that lower military spending within a country is correlated with an increase in the incidence of coups, establishing our empirical finding (ii).

\section{Mechanisms}

Our results show that successful coups lead to changes in military spending that are greater than those that would have taken place if the coups had instead failed. We have also shown that there is a correlation between low within country military spending (as a share of GDP) and the probability of a coup. There are a number of mechanisms that could generate one or the other finding, but we argue that a plausible interpretation that is consistent with both findings is that the military's desire for increased military spending is a motivation for coups, at least when staged against non-democracies. Two of the possible alternative mechanisms connecting military spending and coups also represent threats to identification: (a) the coup plotter's talent or ambition can affect both a coup's outcome and the plotter's ability to increase military spending after a successful coup, and (b) there might be expected shocks, for example to income, that affect both the outcome of a coup and changes in military spending. Other mechanisms include that (c) after a successful coup, the new government

needs to consolidate its power through repression, which shows up as an increase in military spending; (d) the effect we find is largely due to decreases in military spending following failed coups, as governments that survive a coup punish their military; (e) coups are staged for other reasons, but once in power the military acts opportunistically and increases military spending; and (f) lower military spending reflects a smaller military that can more easily 
coordinate when staging a coup.

Alternative (a) is difficult to test directly because the coup plotter's talent is unobservable. However, Table 11 shows that our results are robust to focusing only on coups with casualties, and in these the coup plotter's talent is more likely to be independent of coup outcome. Furthermore, tables 14 and A3 show that successful and failed coups do not seem to differ, one and three years later, in variables like GDP, GDP per capita and political instability, that could also be affected by a coup plotter's talent. Likewise, these tables seem to rule out alternative (b), as there appear to be no differences in variables where shocks could be expected. ${ }^{23}$ Our third alternative (c) is that successful coups lead to a new regime that needs repression to stay in power, and that this requires an increase in military spending. This does not explain why a fall in military spending would increase the likelihood of a coup. It is also at odds with the finding that political instability is the same across successful and failed coups, and that the effect is entirely due to autocracies; there seems to be no compelling reason why more repression would be needed after a successful coup against a non-democracy than after one against a democracy. Alternative (d) can be ruled out too: if military spending falls following a failed coup because the military is being punished, there is no reason why lower military spending before an attempt would be correlated with the likelihood of a coup. Furthermore, it is also inconsistent with Figure 1, which shows that coups lead to an upward shift in the military spending trend for successful coups and virtually no change for failed coups. Alternative (e), that increases in military spending after successful coups simply reflect opportunism, cannot explain why lower military spending increases the likelihood of a coup. Alternative (f) suggests that low military spending simply reflects a smaller military that, being able to easily coordinate, is more likely to stage a coup. This alone, however, cannot explain why military spending goes up following a successful coup.

\footnotetext{
${ }^{23}$ Although it could be possible that successful coups lead to changes in policy that completely prevent these shocks, this seems unlikely.
} 


\section{Concluding Remarks}

This paper studies coups d'etat empirically and finds evidence consistent with the hypothesis that coups are staged by the military in order to increase military expenditures. We show that coups are more likely after years of relatively low military spending, and that successful coups result in increases in military spending that are significantly greater than those following failed coups. Naturally, a number of open issues remain. One question that follows naturally from our results is whether the relationship we have documented between military spending and coups has changed over the four decades covered in our sample. We have shown that coups have become much less common in most regions of the world: is the decline in the number of coups due to a change in the way the military responds to economic incentives? More interestingly, is there any connection between the mechanism we have identified, how it may have changed over time, and the recent waves of democratization? Have these new democracies been "bought" through the provision of generous military funding, or has the military's role in politics changed? Democratization often has a large impact on the military, yet its role in this process has received little attention from economists. 


\section{References}

[1] Acemoglu, Daron, Simon Johnson and James Robinson. 2001. "The Colonial Origins of Comparative Development: An Empirical Investigation." American Economic Review, 91: 1369-1401.

[2] Acemoglu, Daron, Simon Johnson, James Robinson and Pierre Yared. 2008. "Income and Democracy." American Economic Review, 98: 808-842.

[3] Acemoglu, Daron and James Robinson. 2001. "A Theory of Political Transitions." The American Economic Review, 91: 938-963.

[4] Acemoglu, Daron and James Robinson. 2005. Economic Origins of Dictatorship and Democracy. Cambridge: Cambridge University Press.

[5] Acemoglu, Daron, Davide Ticchi, and Andrea Vindigni. 2010. "A Theory of Military Dictatorships." American Economic Journal: Macroeconomics, 2(1): 1-42.

[6] Afrifa, A. A..1966. The Ghana Coup. London: Frank Cass.

[7] Alvarez, Michael, Jose Antonio Cheibub, Fernando Limongi and Adam Przewroski. 1996. "Classifying Political Regimes." Studies in Comparative International Development, 31(2): 3-36.

[8] Banks, A.S.. 2001. Cross-national time-series data archive. Binghamton, NY: Computer Systems Unlimited.

[9] Belkin, Aaron. and Evan Schofer. 2003. "Toward a Structural Understanding of Coup Risk." The Journal of Conflict Resolution, 47: 594-620.

[10] Bertrand, Marianne, Esther Duflo and Sendhil Mullainathan. 2004. "How Much Should We Trust Differences-in-Differences Estimates?" The Quarterly Journal of Economics, 119: $249-275$. 
[11] Besley, Timothy and Masayuki Kudamatsu. 2008. "Making Autocracy Work." In Institutions and Economic Performance, ed. Elhanan Helpman. Cambridge, MA: Harvard University Press.

[12] Besley, Timothy and James Robinson. 2010. "Quis Custodiet Ipsos Custodes? Civilian Control over the Military." Journal of the European Economic Association, 8: 655-663.

[13] Brueckner, Markus and Antonio Ciccone (2010). "International Commodity Prices, Growth, and Civil War in Sub-Saharan Africa." The Economic Journal, 120: 519-534.

[14] Cheibub, Jose Antonio, Jennifer Gandhi and James Raymond Vreeland. 2010. "Democracy and Dictatorship Revisited." Public Choice, 143: 63-101.

[15] Ciccone, Antonio. 2011. "Economic Shocks and Civil Conflict: A Comment." http://www.antoniociccone.eu/wp-content/uploads/2011/02/Transitory-Shocks-Febf2011.pdf

[16] Collier, Paul and Anke Hoeffler. 1998. "On Economic Causes of Civil War." Oxford Economic Papers, 50: 563-573.

[17] Collier, Paul and Anke Hoeffler. 2004. "Greed and Grievance in Civil War." Oxford Economic Papers, 56: 563-595.

[18] Collier, Paul and Anke Hoeffler. 2005. "Coup Traps: Why does Africa have so many Coups d'Etat?." Unpublished manuscript.

[19] Collier, Paul and Anke Heffler. 2007. "Military Spending and the Risks of Coups d'Etat." Unpublished manuscript.

[20] Djankov, Simeon and Marta Reynal-Querol. 2010. "The Causes of Civil War." http://www.econ.upf.edu/ reynal/Civil\%20wars_12December2010.pdf.

[21] Djankov, Simeon and Marta Reynal-Querol. 2010. "Poverty and Civil War: Revisiting the Evidence." Review of Economics and Statistics 92(4): 1035-1041. 
[22] Fearon, James and David Laitin. 2003. "Ethnicity, Insurgency and Civil War." American Political Science Review, 97(1): 75-90.

[23] Feaver, Peter. 2003. Armed Servants: Agency, Oversight and Civil-Military Relations. Cambridge, MA: Harvard University Press.

[24] Finer, Samuel E.. 1962. The Man on Horseback: The Role of the Military in Politics. London: Pall Mall Press.

[25] Huntington, Samuel. 1957. The Soldier and the State: The Theory and Politics of CivilMilitary Relations. Cambridge, MA: Harvard University Press.

[26] Leon, Gabriel. 2009. "Soldiers or Bureaucrats? Conflict and the Military's Role in Policy-Making." http://www.caths.cam.ac.uk/personal/gleon/Military.pdf.

[27] Londregan, John and Keith Poole. 1990. "Poverty, The Coup Trap, and the Seizure of Executive Power." World Politics, 42: 151-183.

[28] Londregan, John and Keith Poole. 1996. "Does High Income Promote Democracy?" World Politics, 49: 1-30.

[29] Luttwak, Edward. 1969. Coup d'Etat: A Practical Handbook. New York: Knopf.

[30] Jones, Benjamin and Benjamin Olken. 2005. "Do Leaders Matter? National Leadership and Growth since World War II." The Quarterly Journal of Economics, 835-864.

[31] Jones, Benjamin and Benjamin Olken. 2009. "Hit or Miss? The Effect of Assassinations on Institutions and War." American Economic Journal: Macroeconomics, 1:2: 55-87.

[32] Marshall, Monty and Donna Ramsey Marshall. 2010. Coup d'Etat Events, 1946-2009. Center for Systemic Peace. 
[33] Miguel, Edward, Shanker Satyanath and Ernest Sergenti. 2004. "Economic Shocks and Civil Conflict: An Instrumental Variables Approach." Journal of Political Economy, 112(4): 725-753.

[34] Mulligan, Casey, Ricard Gil and Xavier Sala-i-Martin. 2004. "Do Democracies Have Different Public Policies than Nondemocracies?" The Journal of Economic Perspectives, 18(1): 51-74.

[35] Nickell, Stephen. 1981. "Biases in Dynamic Models with Fixed Effects." Econometrica, 49: $1417-1426$.

[36] Nordlinger, Eric A.. 1977. Soldiers in Politics: Military Coups and Governments. Englewood Cliffs, NJ: Prentice-Hall.

[37] Powell, Jonathan. 2010. "Explaining the Occurrence and Outcome of Coups d'Etat." http://sweb.uky.edu/ jmpowe4/determinants.pdf.

[38] Powell, Jonathan and Clayton Thyne. 2011. "Global Instances of Coups from 1950Present." Journal of Peace Research, 48(2): 249-259.

[39] Przeworski, Adam, Michael Alvarez, Jose Antonio Cheibub and Fernando Limongi. 2000. Democracy and Development: Political Institutions and Well-Being in the World, 1950-1990. Cambridge: Cambridge University Press. 
Table 1: Coups

(1963-1999)

\begin{tabular}{lcc}
\hline \hline & Number & Percentage \\
\cline { 2 - 3 } Country-Years, All & 4,513 & $94.81 \%$ \\
Country-Years, & 247 & $5.19 \%$ \\
With Coups & & $100 \%$ \\
\hline Total & 4,760 & \\
\hline \hline
\end{tabular}

Notes: The coup data is from Belkin and Schofer (2003).

Table 2: Coup Success and Failure (1963-1999)

\begin{tabular}{lcc}
\hline \hline & Number & Percentage \\
\cline { 2 - 3 } Success & 117 & $50.43 \%$ \\
Failure & 115 & $49.57 \%$ \\
\hline Total & 232 & $100 \%$
\end{tabular}

Notes: The coup data is from Belkin and Schofer (2003), Banks (2001), and Powell and Thyne (2011).

\section{Table 3: Countries with Coups} (1963-1999)

(Experienced at Least 1 Coup in this period)

\begin{tabular}{lcc}
\hline & Countries & Percentage \\
\cline { 2 - 3 } Yes & 74 & $48 \%$ \\
No & 79 & $52 \%$ \\
\hline Total & 153 & $100 \%$ \\
\hline \hline
\end{tabular}

Notes: The coup data is from Belkin and Schofer (2003). 
Table 4: Average Number of Coups

(by Country-Year)

\begin{tabular}{|c|c|c|c|c|}
\hline \multirow[b]{2}{*}{ Region } & \multicolumn{4}{|c|}{ Decade } \\
\hline & 60 & 70 & 80 & 90 \\
\hline Sub-Saharan Africa & 0.1627 & 0.1362 & 0.0792 & 0.0810 \\
\hline Latin America \& Caribbean & 0.1325 & 0.1256 & 0.0609 & 0.0435 \\
\hline Europe \& Central Asia & 0.0119 & 0.0417 & 0.0167 & 0.0175 \\
\hline East Asia \& Pacific & 0.0446 & 0.0663 & 0.0333 & 0.0111 \\
\hline Middle East \& North Africa & 0.1538 & 0.0511 & 0 & 0.0294 \\
\hline South Asia & 0.0357 & 0.1321 & 0.0441 & 0.0714 \\
\hline North America & 0 & 0 & 0 & 0 \\
\hline All Countries in Dataset & 0.0983 & 0.0929 & 0.0450 & 0.0416 \\
\hline Observations & 780 & 1,194 & 1,320 & 1,466 \\
\hline
\end{tabular}

Notes: The coup data is from Belkin and Schofer (2003). Regions are as defined by the World Bank. Country-years for which there is no coup information are dropped. The 1960s decade only includes the years 1963-1969. 


\section{Table 5: Coups and Transitions}

(1963-1999)

\begin{tabular}{|c|c|c|}
\hline $\begin{array}{c}\text { Coup Against: } \\
\text { (year before) }\end{array}$ & Outcome: & $\begin{array}{l}\text { New Regime: } \\
\text { (year after) }\end{array}$ \\
\hline \multirow{8}{*}{$\frac{\text { Democracy }}{48}$} & $\underline{\text { Success }}$ & Democracy \\
\hline & \multirow[t]{3}{*}{26} & 1 \\
\hline & & Non-Democracy \\
\hline & & 24 \\
\hline & Failure & Democracy \\
\hline & \multirow[t]{3}{*}{22} & 18 \\
\hline & & Non-Democracy \\
\hline & & 2 \\
\hline Autocracy & $\underline{\text { Success }}$ & Democracy \\
\hline \multirow[t]{7}{*}{185} & \multirow[t]{3}{*}{84} & 7 \\
\hline & & Non-Democracy \\
\hline & & 74 \\
\hline & Failure & Democracy \\
\hline & \multirow[t]{3}{*}{87} & 6 \\
\hline & & Non-Democracy \\
\hline & & 80 \\
\hline
\end{tabular}

Successful Coups

\begin{tabular}{ccc}
\hline $\begin{array}{c}\text { New Regime: } \\
\text { (year after) }\end{array}$ & Democracy & Autocracy \\
\hline & 8 & 105
\end{tabular}

Notes: Regime data is missing for some coups. The coup data is from Belkin and Schofer (2003), Banks (2001), and Powell and Thyne (2011). The regime data is from Cheibub, Gandhi and Vreeland (2010). 
Table 6: Average Military Expenditures / GDP

(by Country-Year)

\begin{tabular}{|c|c|c|c|c|}
\hline \multirow[b]{2}{*}{ Region } & \multicolumn{4}{|c|}{ Decade } \\
\hline & 60 & 70 & 80 & 90 \\
\hline Sub-Saharan Africa & 1.85 & 3.08 & 3.63 & 3.07 \\
\hline Latin America \& Caribbean & 1.65 & 1.85 & 2.76 & 1.84 \\
\hline Europe \& Central Asia & 3.40 & 3.44 & 5.23 & 4.97 \\
\hline East Asia \& Pacific & 4.30 & 6.44 & 3.85 & 3.35 \\
\hline Middle East \& North Africa & 7.32 & 13.06 & 14.38 & 12.19 \\
\hline South Asia & 3.25 & 3.08 & 2.99 & 2.86 \\
\hline North America & 6.00 & 3.78 & 3.93 & 2.69 \\
\hline All Countries in Dataset & 3.15 & 4.43 & 5.22 & 4.50 \\
\hline Observations & 613 & 1,021 & 1,073 & 1,281 \\
\hline
\end{tabular}

Notes: The military expenditures data is from the U.S. Arms Control Disarmament Agency's "World Military Expenditures and Arms Transfers” reports. Regions are as defined by the World Bank. Country-years for which there is no coup information are dropped. The 1960s decade only includes the period 1963-1969. 
Table 7: Summary Statistics

\begin{tabular}{lccc}
\hline \hline & Mean & Std. Deviation & Observations \\
\cline { 2 - 4 } Coups & 0.05 & 0.22 & 4,760 \\
Military Expenditures / GDP (Total=100) & 4.47 & 6.53 & 3,988 \\
Military Expenditures (Millions, 2000\$) & 5,763 & 28,471 & 4331 \\
GDP per capita (2000\$) & 5,080 & 7,656 & 4,144 \\
GDP (Millions, 2000\$) & 145,645 & 636,387 & 4,147 \\
Population (in Millions) & 31.55 & 112.11 & 4,678 \\
Size of Military (in Millions) & 0.15 & 0.41 & 4,653 \\
Democracy & 0.39 & 0.49 & 5,905 \\
Military Regime & 0.21 & 0.41 & 5,931 \\
Instability & 3,024 & 7,748 & 4,595 \\
\hline \hline
\end{tabular}

Notes: Coups is a binary variable equal to 1 if there was at least one coup in that country-year, 0 otherwise; Democracy is a binary variable that equals 1 if the country was democratic and 0 othewise; Military Regime equals 1 if the government was in the hands of the military, 0 otherwise; Instability measures political instability and is from Banks (2001). 
Figure 1: Trends in Military Spending / GDP

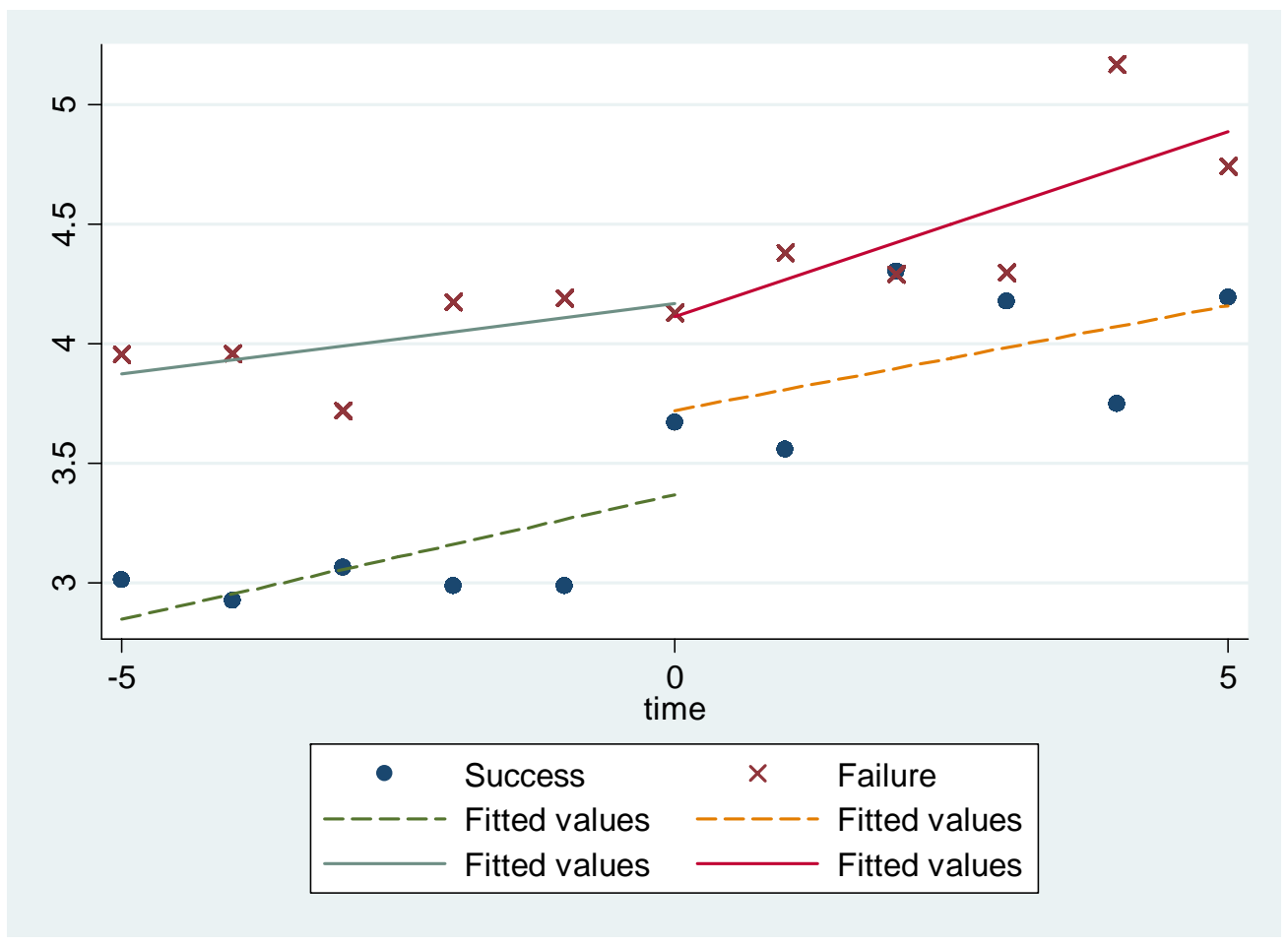

The trends are constructed by fitting lines that go through the mean military spending for each group in each year $t$, where $t=0$ corresponds to the year in which the coup took place. Negative values of $t$ refer to years before the coup; positive values refer to years after the coup. 
Table 8: Comparing the Treatment and Control Groups

\begin{tabular}{|c|c|c|c|c|c|c|}
\hline \multirow[b]{3}{*}{ Military Exp/GDP ${ }_{t-1}$} & \multicolumn{6}{|c|}{ Comparing Successful and Failed Coups, Year before Coup } \\
\hline & Failure & Obs. & Success & Obs. & $\begin{array}{c}\text { Difference } \\
\text { (Failure - Success) }\end{array}$ & $\begin{array}{c}\mathrm{p} \text {-value } \\
\text { (two-sided t-tests) }\end{array}$ \\
\hline & $\begin{array}{c}4.86 \\
(5.38)\end{array}$ & 55 & $\begin{array}{c}3.05 \\
(2.47)\end{array}$ & 62 & 1.81 & 0.02 \\
\hline Military $\operatorname{Exp}_{\mathrm{t}-1}(\log )$ & $\begin{array}{c}5.32 \\
(1.81)\end{array}$ & 60 & $\begin{array}{c}4.99 \\
(1.81)\end{array}$ & 66 & 0.33 & 0.30 \\
\hline GDP per capita $\mathrm{t}-1(\log )$ & $\begin{array}{c}6.38 \\
(1.14)\end{array}$ & 51 & $\begin{array}{l}6.23 \\
(.92)\end{array}$ & 62 & 0.15 & 0.43 \\
\hline $\operatorname{GDP}_{\mathrm{t}-1}(\log )$ & $\begin{array}{c}8.30 \\
(1.67)\end{array}$ & 51 & $\begin{array}{c}8.19 \\
(1.70)\end{array}$ & 62 & 0.11 & 0.73 \\
\hline Population $_{\mathrm{t}-1}(\log )$ & $\begin{array}{c}1.92 \\
(1.14)\end{array}$ & 64 & $\begin{array}{l}1.95 \\
(1.37)\end{array}$ & 71 & -0.03 & 0.89 \\
\hline Size of Military $t-1(\log )$ & $\begin{array}{l}-3.75 \\
(1.54)\end{array}$ & 62 & $\begin{array}{l}-3.82 \\
(1.70)\end{array}$ & 67 & 0.07 & 0.82 \\
\hline Democracy $t-1$ & $\begin{array}{l}.26 \\
(.44)\end{array}$ & 66 & $\begin{array}{l}.27 \\
(.45)\end{array}$ & 71 & -0.01 & 0.89 \\
\hline Military Regime ${ }_{t-1}$ & $\begin{array}{l}.41 \\
(.50)\end{array}$ & 66 & $\begin{array}{l}.34 \\
(.48)\end{array}$ & 71 & 0.07 & 0.39 \\
\hline Instability $\mathrm{t}-1$ & $\begin{array}{c}3.27 \\
(5.30)\end{array}$ & 61 & $\begin{array}{c}3.03 \\
(5.68)\end{array}$ & 68 & 0.24 & 0.81 \\
\hline
\end{tabular}

Notes: Standard deviations are in parentheses. Military expenditures as a fraction of GDP and in levels are from the U.S. Arms Control and Disarmament Agency. Military expenditures and GDP are in millions of US\$ (2000), GDP per capita is in US\$ (2000), population and the size of the military are in millions. Democracy and Regime measure whether the country is democratic and whether it is ruled by a military government, respectively. Instability is measured in thousands of units. All variables are dated the year before the coup. 
Table 9: Predicting Coup Outcome

\begin{tabular}{|c|c|c|c|c|c|c|c|c|}
\hline & \multicolumn{4}{|c|}{ Linear Probability Model } & \multicolumn{4}{|c|}{ Logit } \\
\hline & (1) & (2) & (3) & (4) & (5) & (6) & (7) & (8) \\
\hline & $\begin{array}{c}\text { Coup } \\
\text { Success }_{t}\end{array}$ & $\begin{array}{c}\text { Coup } \\
\text { Success }_{t}\end{array}$ & $\begin{array}{c}\text { Coup } \\
\text { Success }_{t}\end{array}$ & $\begin{array}{c}\text { Coup } \\
\text { Success }_{t}\end{array}$ & $\begin{array}{c}\text { Coup } \\
\text { Success } \\
\end{array}$ & $\begin{array}{c}\text { Coup } \\
\text { Success } t\end{array}$ & $\begin{array}{c}\text { Coup } \\
\text { Success } t\end{array}$ & $\begin{array}{c}\text { Coup } \\
\text { Success } t\end{array}$ \\
\hline Military Exp/GDP ${ }_{t-1}$ & $\begin{array}{l}-0.020 \\
(0.020)\end{array}$ & $\begin{array}{l}-0.021 \\
(0.020)\end{array}$ & & & $\begin{array}{l}-0.099 \\
(0.094)\end{array}$ & $\begin{array}{l}-0.109 \\
(0.102)\end{array}$ & & \\
\hline Military $\operatorname{Exp}_{\mathrm{t}-1}(\log )$ & & & $\begin{array}{l}-0.080 \\
(0.085)\end{array}$ & $\begin{array}{c}-0.094 \\
(0.086)\end{array}$ & & & $\begin{array}{c}-0.377 \\
(0.379)\end{array}$ & $\begin{array}{l}-0.445 \\
(0.390)\end{array}$ \\
\hline GDP per capita $t-1(\log )$ & $\begin{array}{c}-0.103 * \\
(0.061)\end{array}$ & & $\begin{array}{l}-0.029 \\
(0.061)\end{array}$ & & $\begin{array}{c}-0.520 * \\
(0.298)\end{array}$ & & $\begin{array}{l}-0.130 \\
(0.289)\end{array}$ & \\
\hline $\operatorname{GDP}_{\mathrm{t}-1}(\log )$ & & $\begin{array}{l}-0.110 \\
(0.079)\end{array}$ & & $\begin{array}{c}-0.011 \\
(0.075)\end{array}$ & & $\begin{array}{l}-0.559 \\
(0.375)\end{array}$ & & $\begin{array}{l}-0.049 \\
(0.333)\end{array}$ \\
\hline Population $_{\mathrm{t}-1}(\log )$ & & $\begin{array}{c}0.089 \\
(0.097)\end{array}$ & & $\begin{array}{c}0.058 \\
(0.103)\end{array}$ & & $\begin{array}{c}0.446 \\
(0.434)\end{array}$ & & $\begin{array}{c}0.270 \\
(0.458)\end{array}$ \\
\hline Size of Military t-1 $(\log )$ & $\begin{array}{c}0.057 \\
(0.054)\end{array}$ & $\begin{array}{c}0.073 \\
(0.103)\end{array}$ & $\begin{array}{c}0.103 \\
(0.096)\end{array}$ & $\begin{array}{c}0.083 \\
(0.107)\end{array}$ & $\begin{array}{c}0.287 \\
(0.249)\end{array}$ & $\begin{array}{c}0.371 \\
(0.465)\end{array}$ & $\begin{array}{c}0.490 \\
(0.448)\end{array}$ & $\begin{array}{c}0.403 \\
(0.476)\end{array}$ \\
\hline Democracy $t-1$ & $\begin{array}{l}-0.157 \\
(0.181)\end{array}$ & $\begin{array}{l}-0.153 \\
(0.182)\end{array}$ & $\begin{array}{l}-0.072 \\
(0.170)\end{array}$ & $\begin{array}{l}-0.087 \\
(0.171)\end{array}$ & $\begin{array}{c}-0.791 \\
(0.862)\end{array}$ & $\begin{array}{l}-0.779 \\
(0.857)\end{array}$ & $\begin{array}{c}-0.354 \\
(0.764)\end{array}$ & $\begin{array}{l}-0.426 \\
(0.760)\end{array}$ \\
\hline Military Regime $_{\mathrm{t}-1}$ & $\begin{array}{l}-0.136 \\
(0.142)\end{array}$ & $\begin{array}{l}-0.135 \\
(0.142)\end{array}$ & $\begin{array}{c}-0.083 \\
(0.139)\end{array}$ & $\begin{array}{l}-0.085 \\
(0.139)\end{array}$ & $\begin{array}{c}-0.689 \\
(0.690)\end{array}$ & $\begin{array}{c}-0.686 \\
(0.684)\end{array}$ & $\begin{array}{c}-0.392 \\
(0.618)\end{array}$ & $\begin{array}{c}-0.404 \\
(0.615)\end{array}$ \\
\hline Instability $\mathrm{t}-1$ & $\begin{array}{c}-0.001 \\
(0.013)\end{array}$ & $\begin{array}{c}-0.001 \\
(0.013)\end{array}$ & $\begin{array}{c}0.003 \\
(0.012)\end{array}$ & $\begin{array}{c}0.003 \\
(0.012)\end{array}$ & $\begin{array}{c}-0.006 \\
(0.053)\end{array}$ & $\begin{array}{l}-0.005 \\
(0.052)\end{array}$ & $\begin{array}{c}0.012 \\
(0.049)\end{array}$ & $\begin{array}{c}0.011 \\
(0.050)\end{array}$ \\
\hline Region and Decade FE & YES & YES & YES & YES & YES & YES & YES & YES \\
\hline $\begin{array}{l}\text { Test: All coefficients } \\
\text { (excl. fixed effects) }\end{array}$ & $\begin{array}{c}\text { F: } 0.62 \\
\text { p-val: } 0.71\end{array}$ & $\begin{array}{c}\text { F: } 0.53 \\
\text { p-val: } 0.81\end{array}$ & $\begin{array}{c}\text { F: } 0.29 \\
\text { p-val: } 0.94\end{array}$ & $\begin{array}{c}\text { F: } 0.28 \\
\text { p-val: } 0.96\end{array}$ & $\begin{array}{c}\text { Chi2(6): } 3.46 \\
\text { p-val: } 0.75\end{array}$ & $\begin{array}{c}\text { Chi2(7): } 3.45 \\
\text { p-val: } 0.84 \\
\end{array}$ & $\begin{array}{c}\text { Chi2(6): } 1.74 \\
\text { p-val: } 0.69 \\
\end{array}$ & $\begin{array}{c}\text { Chi2(7): } 1.95 \\
\text { p-val: } 0.96 \\
\end{array}$ \\
\hline Observations (\# of coups) & 99 & 99 & 100 & 100 & 99 & 99 & 100 & 100 \\
\hline R-squared / Pseudo R2 & 0.17 & 0.17 & 0.13 & 0.14 & 0.13 & 0.13 & 0.10 & 0.10 \\
\hline
\end{tabular}

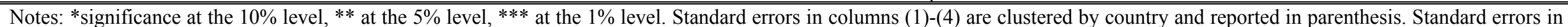

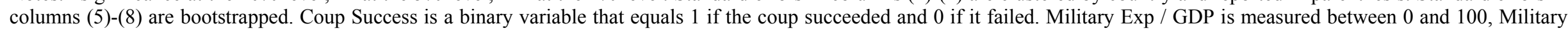

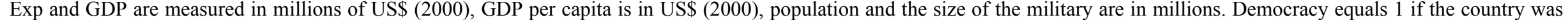
democratic and 0 otherwise; Military Regime equals 1 if the government was in the hands of the military, 0 otherwise. Instability is measured in thousands. 
Table 10: Difference in Differences

(One Year Before and After)

\begin{tabular}{|c|c|c|c|c|c|c|}
\hline & (1) & (2) & (3) & (4) & (5) & (6) \\
\hline & $\begin{array}{l}\text { Military } \\
\text { Exp/GDP }\end{array}$ & $\begin{array}{l}\text { Military } \\
\text { Exp/GDP }\end{array}$ & $\begin{array}{l}\text { Military } \\
\text { Exp/GDP }\end{array}$ & $\begin{array}{l}\text { Military Exp } \\
(\log )\end{array}$ & $\begin{array}{l}\text { Military Exp } \\
(\log )\end{array}$ & $\begin{array}{c}\text { Military Exp } \\
(\log )\end{array}$ \\
\hline Post-Coup dummy $\left(\beta_{1}\right)$ & $\begin{array}{c}-0.421 * * \\
(0.374)\end{array}$ & $\begin{array}{c}-0.490 * \\
(0.287)\end{array}$ & $\begin{array}{l}-0.386 \\
(0.288)\end{array}$ & $\begin{array}{c}-0.012 \\
(0.161)\end{array}$ & $\begin{array}{l}-0.106 \\
(0.097)\end{array}$ & $\begin{array}{l}-0.135 \\
(0.092)\end{array}$ \\
\hline Success dummy $\left(\beta_{2}\right)$ & $\begin{array}{c}-1.815^{* *} \\
(0.807)\end{array}$ & $\begin{array}{l}-0.672 \\
(0.469)\end{array}$ & $\begin{array}{l}-0.635 \\
(0.446)\end{array}$ & $\begin{array}{l}-0.334 \\
(0.344)\end{array}$ & $\begin{array}{l}-0.163 \\
(0.131)\end{array}$ & $\begin{array}{l}-0.167 \\
(0.117)\end{array}$ \\
\hline $\begin{array}{l}\text { Post_Coup x Success } \\
\text { Dummies }\left(\beta_{3}\right)\end{array}$ & $\begin{array}{l}1.438 * * \\
(0.686)\end{array}$ & $\begin{array}{l}0.812 * * \\
(0.370)\end{array}$ & $\begin{array}{l}0.740 * \\
(0.382)\end{array}$ & $\begin{array}{c}0.077 \\
(0.218)\end{array}$ & $\begin{array}{l}0.251 * * \\
(0.124)\end{array}$ & $\begin{array}{l}0.271 * * \\
(0.120)\end{array}$ \\
\hline GDP per capita (log) & & $\begin{array}{c}-1.122 * * * \\
(0.397)\end{array}$ & & & $\begin{array}{c}0.293 * * * \\
(0.087)\end{array}$ & \\
\hline GDP (log) & & & $\begin{array}{c}-1.559 * * * \\
(0.420)\end{array}$ & & & $\begin{array}{c}0.421 * * * \\
(0.079)\end{array}$ \\
\hline Population (log) & & & $\begin{array}{l}-0.026 \\
(0.548)\end{array}$ & & & $\begin{array}{c}0.026 \\
(0.113)\end{array}$ \\
\hline Size of Military t-1 $(\log )$ & & $\begin{array}{l}0.558 * * * \\
(0.179)\end{array}$ & $\begin{array}{l}1.668 * * * \\
(0.446)\end{array}$ & & $\begin{array}{c}0.949 * * * \\
(0.058)\end{array}$ & $\begin{array}{c}0.633 * * * \\
(0.092)\end{array}$ \\
\hline Democracy t-1 & & $\begin{array}{c}-1.885 * * \\
(0.896)\end{array}$ & $\begin{array}{l}-1.295 \\
(0.797)\end{array}$ & & $\begin{array}{c}0.106 \\
(0.170)\end{array}$ & $\begin{array}{l}-0.053 \\
(0.154)\end{array}$ \\
\hline Military Regime $_{\mathrm{t}-1}$ & & $\begin{array}{l}-1.130 \\
(0.693)\end{array}$ & $\begin{array}{l}-0.944 \\
(0.570)\end{array}$ & & $\begin{array}{c}0.020 \\
(0.124)\end{array}$ & $\begin{array}{l}-0.027 \\
(0.128)\end{array}$ \\
\hline Instability $\mathrm{t}-1$ & & $\begin{array}{l}-0.017 \\
(0.034)\end{array}$ & $\begin{array}{l}-0.004 \\
(0.034)\end{array}$ & & $\begin{array}{c}0.010 \\
(0.009)\end{array}$ & $\begin{array}{c}0.007 \\
(0.008)\end{array}$ \\
\hline Region and Decade FE & $\mathrm{NO}$ & YES & YES & $\mathrm{NO}$ & YES & YES \\
\hline$\Delta$ after Successful Coup $\left(\beta_{1}+\beta_{3}\right)$ & 1.017 & 0.322 & 0.354 & 0.065 & 0.145 & 0.136 \\
\hline Test: Successful Coup not 0 & $0.33(0.567)$ & $0.11(0.740)$ & $0.06(0.809)$ & $0.68(0.412)$ & $0.46(0.501)$ & $0.86(0.359)$ \\
\hline Observations & 243 & 194 & 194 & 257 & 196 & 196 \\
\hline R-squared & 0.022 & 0.383 & 0.444 & 0.007 & 0.896 & 0.910 \\
\hline
\end{tabular}

Notes: *significance at the $10 \%$ level, $* *$ at the $5 \%$ level, $* * *$ at the $1 \%$ level. Standard errors are clustered by country and reported in parenthesis. Military Exp / GDP is measured between 0 and 100, Military Exp and GDP are in millions of US\$ (2000), GDP per capita is in US\$ (2000), population and the size of the military are in millions. Instability is measured in thousands. Test is an F-test, with the F-statistic followed by the p-value in parenthesis. 
Table 11: Difference in Differences: Coups with Reported Deaths (One Year Before and After)

\begin{tabular}{|c|c|c|c|c|}
\hline & (1) & (2) & (3) & (4) \\
\hline & Military Exp/GDP & Military Exp/GDP & Military Exp (log) & Military Exp (log) \\
\hline Post-Coup dummy $\left(\beta_{1}\right)$ & $\begin{array}{l}-0.819 \\
(0.597)\end{array}$ & $\begin{array}{c}-0.688 \\
(0.590)\end{array}$ & $\begin{array}{l}-0.178 \\
(0.192)\end{array}$ & $\begin{array}{l}-0.245 \\
(0.199)\end{array}$ \\
\hline Success dummy $\left(\beta_{2}\right)$ & $\begin{array}{l}-1.063 \\
(0.643)\end{array}$ & $\begin{array}{l}-0.690 \\
(0.601)\end{array}$ & $\begin{array}{l}-0.150 \\
(0.309)\end{array}$ & $\begin{array}{l}-0.343 \\
(0.236)\end{array}$ \\
\hline $\begin{array}{l}\text { Post_Coup x Success } \\
\text { Dummies }\left(\beta_{3}\right)\end{array}$ & $\begin{array}{l}1.679 * \\
(0.853)\end{array}$ & $\begin{array}{l}1.589 * \\
(0.800)\end{array}$ & $\begin{array}{l}0.522 * * \\
(0.245)\end{array}$ & $\begin{array}{l}0.566 * * \\
(0.271)\end{array}$ \\
\hline GDP per capita (log) & $\begin{array}{l}-0.582 \\
(0.600)\end{array}$ & & $\begin{array}{l}0.563 * * \\
(0.214)\end{array}$ & \\
\hline GDP (log) & & $\begin{array}{l}-0.736 \\
(0.512)\end{array}$ & & $\begin{array}{c}0.662 * * * \\
(0.158)\end{array}$ \\
\hline Population (log) & & $\begin{array}{l}-0.377 \\
(0.622)\end{array}$ & & $\begin{array}{l}-0.065 \\
(0.205)\end{array}$ \\
\hline Size of Military t-1 $(\log )$ & $\begin{array}{c}0.964 * * * \\
(0.203)\end{array}$ & $\begin{array}{c}1.664 * * * \\
(0.403)\end{array}$ & $\begin{array}{c}0.990 * * * \\
(0.094)\end{array}$ & $\begin{array}{l}0.599 * * * \\
(0.103)\end{array}$ \\
\hline Democracy $\mathrm{t}-1$ & $\begin{array}{l}-0.884^{*} \\
(0.657)\end{array}$ & $\begin{array}{l}-0.268 \\
(0.723)\end{array}$ & $\begin{array}{c}0.221 \\
(0.326)\end{array}$ & $\begin{array}{c}-0.099 \\
(0.248)\end{array}$ \\
\hline Military Regime $_{\mathrm{t}-1}$ & $\begin{array}{c}-0.122 \\
0.567\end{array}$ & $\begin{array}{l}-0.041 \\
(0.495)\end{array}$ & $\begin{array}{c}0.146 \\
(0.258)\end{array}$ & $\begin{array}{c}0.117 \\
(0.178)\end{array}$ \\
\hline Instability $\mathrm{t}-1$ & $\begin{array}{c}-0.145 * * \\
(0.062)\end{array}$ & $\begin{array}{l}-0.140 * * \\
(0.054)\end{array}$ & $\begin{array}{c}0.006 \\
(0.016)\end{array}$ & $\begin{array}{c}0.007 \\
(0.017)\end{array}$ \\
\hline Region and Decade FE & Yes & Yes & Yes & Yes \\
\hline$\Delta$ after Successful Coup $\left(\beta_{1}+\beta_{3}\right)$ & 0.86 & 0.901 & 0.344 & 0.321 \\
\hline Test: Successful Coup not 0 & $2.38(0.136)$ & $3.14(0.089)$ & $5.20(0.031)$ & $3.38(0.078)$ \\
\hline Observations & 60 & 60 & 62 & 62 \\
\hline R-squared & 0.671 & 0.713 & 0.884 & 0.911 \\
\hline
\end{tabular}

Notes: *significance at the $10 \%$ level, $* *$ at the $5 \%$ level, $* * *$ at the $1 \%$ level. Standard errors are clustered by country and reported in parenthesis. Military Exp / GDP is measured between 0 and 100, Military Exp and GDP are in millions of US\$ (2000), GDP per capita is in US\$ (2000), population and the size of the military are in millions. Democracy equals 1 if the country was democratic and 0 otherwise; Military Regime equals 1 if the government was in the hands of the military, 0 otherwise. Instability is measured in thousands. Test is an F-test, with the F-statistic followed by the p-value in parenthesis. 
Table 12: Difference in Differences, Democracies (One Year Before and After)

\begin{tabular}{|c|c|c|c|c|c|c|}
\hline & (1) & (2) & (3) & (4) & $(5)$ & (6) \\
\hline & $\begin{array}{l}\text { Military } \\
\text { Exp/GDP }\end{array}$ & $\begin{array}{l}\text { Military } \\
\text { Exp/GDP }\end{array}$ & $\begin{array}{l}\text { Military } \\
\text { Exp/GDP }\end{array}$ & $\begin{array}{l}\text { Military Exp } \\
(\log )\end{array}$ & $\begin{array}{l}\text { Military Exp } \\
(\log )\end{array}$ & $\begin{array}{l}\text { Military Exp } \\
(\log )\end{array}$ \\
\hline Post-Coup dummy $\left(\beta_{1}\right)$ & $\begin{array}{l}0.649 * \\
(0.351)\end{array}$ & $\begin{array}{c}0.381 \\
(0.301)\end{array}$ & $\begin{array}{c}0.469 \\
(0.295)\end{array}$ & $\begin{array}{c}0.436 * * * \\
(0.145)\end{array}$ & $\begin{array}{l}0.181 * \\
(0.101)\end{array}$ & $\begin{array}{c}0.137 \\
(0.099)\end{array}$ \\
\hline Success dummy $\left(\beta_{2}\right)$ & $\begin{array}{c}0.104 \\
(0.690)\end{array}$ & $\begin{array}{l}-0.947 * \\
(0.529)\end{array}$ & $\begin{array}{c}-1.015 * * \\
(0.460)\end{array}$ & $\begin{array}{c}0.177 \\
(0.608)\end{array}$ & $\begin{array}{l}-0.350 * \\
(0.191)\end{array}$ & $\begin{array}{l}-0.312 * \\
(0.167)\end{array}$ \\
\hline $\begin{array}{l}\text { Post_Coup x Success } \\
\text { Dummies }\left(\beta_{3}\right)\end{array}$ & $\begin{array}{l}-0.320 \\
(0.534)\end{array}$ & $\begin{array}{c}0.001 \\
(0.442)\end{array}$ & $\begin{array}{l}-0.044 \\
(0.423)\end{array}$ & $\begin{array}{l}-0.327 \\
(0.206)\end{array}$ & $\begin{array}{c}0.068 \\
(0.147)\end{array}$ & $\begin{array}{c}0.077 \\
(0.147)\end{array}$ \\
\hline GDP per capita $(\log )$ & & $\begin{array}{c}0.610 \\
(0.434)\end{array}$ & & & $\begin{array}{l}0.985 * * * \\
(0.121)\end{array}$ & \\
\hline GDP (log) & & & $\begin{array}{c}0.462 \\
(0.286)\end{array}$ & & & $\begin{array}{l}1.065 * * * \\
(0.111)\end{array}$ \\
\hline Population (log) & & & $\begin{array}{c}-1.770 * * * \\
(0.384)\end{array}$ & & & $\begin{array}{c}-0.537 * * * \\
(0.156)\end{array}$ \\
\hline Size of Military $\mathrm{t}-1(\log )$ & & $\begin{array}{l}0.556 * * \\
(0.239)\end{array}$ & $\begin{array}{l}1.480 * * * \\
(0.336)\end{array}$ & & $\begin{array}{c}0.937 * * * \\
(0.060)\end{array}$ & $\begin{array}{l}0.561 * * * \\
(0.104)\end{array}$ \\
\hline \multicolumn{7}{|l|}{ Democracy $\mathrm{t}-1$} \\
\hline \multicolumn{7}{|l|}{ Military Regime $_{\mathrm{t}-1}$} \\
\hline Instability $\mathrm{t}-1$ & & $\begin{array}{l}-0.026 \\
(0.019)\end{array}$ & $\begin{array}{l}-0.024 * \\
(0.018)\end{array}$ & & $\begin{array}{c}0.005 \\
(0.007)\end{array}$ & $\begin{array}{c}0.003 \\
(0.006)\end{array}$ \\
\hline Region and Decade FE & $\mathrm{NO}$ & YES & YES & NO & YES & YES \\
\hline$\Delta$ after Successful Coup $\left(\beta_{1}+\beta_{3}\right)$ & 0.329 & 0.382 & 0.425 & 0.109 & 0.249 & 0.214 \\
\hline Test: Successful Coup not 0 & $0.14(0.713)$ & $2.42(0.135)$ & $5.24(0.033)$ & $0.07(0.797)$ & $2.61(0.121)$ & $1.96(0.177)$ \\
\hline Observations & 63 & 63 & 63 & 63 & 63 & 63 \\
\hline R-squared & 0.024 & 0.487 & 0.601 & 0.009 & 0.932 & 0.949 \\
\hline
\end{tabular}

Notes: *significance at the $10 \%$ level, $* *$ at the $5 \%$ level, $* * *$ at the $1 \%$ level. Standard errors are clustered by country and reported in parenthesis. Military Exp / GDP is measured between 0 and 100, Military Exp and GDP are in millions of US\$ (2000), GDP per capita is in US\$ (2000), population and the size of the military are in millions. Instability is measured in thousands. Test is an F-test, with the F-statistic followed by the p-value in parenthesis. 
Table 13: Difference in Differences, Non-Democracies

(One Year Before and After)

\begin{tabular}{|c|c|c|c|c|c|c|}
\hline & (1) & (2) & (3) & (4) & (5) & (6) \\
\hline & $\begin{array}{l}\text { Military } \\
\text { Exp/GDP }\end{array}$ & $\begin{array}{c}\text { Military } \\
\text { Exp/GDP }\end{array}$ & $\begin{array}{c}\text { Military } \\
\text { Exp/GDP }\end{array}$ & $\begin{array}{l}\text { Military Exp } \\
(\log )\end{array}$ & $\begin{array}{l}\text { Military Exp } \\
(\log )\end{array}$ & $\begin{array}{c}\text { Military Exp } \\
(\log )\end{array}$ \\
\hline Post-Coup dummy $\left(\beta_{1}\right)$ & $\begin{array}{c}-0.907 * \\
(0.479)\end{array}$ & $\begin{array}{c}-0.812 * * \\
(0.396)\end{array}$ & $\begin{array}{c}-0.697 * \\
(0.383)\end{array}$ & $\begin{array}{c}-0.098 \\
(0.202)\end{array}$ & $\begin{array}{c}-0.239 * \\
(0.124)\end{array}$ & $\begin{array}{c}-0.256^{* *} \\
(0.122)\end{array}$ \\
\hline Success dummy $\left(\beta_{2}\right)$ & $\begin{array}{l}-2.519 * * \\
(1.029)\end{array}$ & $\begin{array}{l}-0.724 \\
(0.659)\end{array}$ & $\begin{array}{l}-0.505 \\
(0.609)\end{array}$ & $\begin{array}{l}-0.554 \\
(0.392)\end{array}$ & $\begin{array}{l}-0.126 \\
(0.156)\end{array}$ & $\begin{array}{l}-0.147 \\
(0.140)\end{array}$ \\
\hline $\begin{array}{l}\text { Post_Coup x Success } \\
\text { Dummies }\left(\beta_{3}\right)\end{array}$ & $\begin{array}{c}2.098 * * \\
(0.860)\end{array}$ & $\begin{array}{l}1.082 * * \\
(0.504)\end{array}$ & $\begin{array}{l}0.953 * \\
(0.510)\end{array}$ & $\begin{array}{c}0.220 \\
(0.273)\end{array}$ & $\begin{array}{l}0.333 * \\
(0.170)\end{array}$ & $\begin{array}{l}0.351 * * \\
(0.168)\end{array}$ \\
\hline GDP per capita $(\log )$ & & $\begin{array}{c}-1.153 * * \\
(0.453)\end{array}$ & & & $\begin{array}{c}0.188 * * \\
(0.080)\end{array}$ & \\
\hline GDP $(\log )$ & & & $\begin{array}{c}-1.915^{* * *} \\
(0.503)\end{array}$ & & & $\begin{array}{c}0.300 * * * \\
(0.083)\end{array}$ \\
\hline Population (log) & & & $\begin{array}{l}-0.333 \\
(0.640)\end{array}$ & & & $\begin{array}{c}0.013 \\
(0.109)\end{array}$ \\
\hline Size of Military t-1 $(\log )$ & & $\begin{array}{l}0.439 * \\
(0.229)\end{array}$ & $\begin{array}{l}1.983 * * * \\
(0.604)\end{array}$ & & $\begin{array}{c}0.917 * * * \\
(0.063)\end{array}$ & $\begin{array}{c}0.697 * * * \\
(0.104)\end{array}$ \\
\hline \multicolumn{7}{|l|}{ Democracy t-1 } \\
\hline Military Regime ${ }_{t-1}$ & & $\begin{array}{l}-1.047 \\
(0.688)\end{array}$ & $\begin{array}{l}-0.834 \\
(0.501)\end{array}$ & & $\begin{array}{c}0.006 \\
(0.112)\end{array}$ & $\begin{array}{l}-0.018 \\
(0.110)\end{array}$ \\
\hline Instability $\mathrm{t}-1$ & & $\begin{array}{c}0.193 \\
(0.071)\end{array}$ & $\begin{array}{c}0.219 * * * \\
(0.054)\end{array}$ & & $\begin{array}{c}0.058 \\
(0.016)\end{array}$ & $\begin{array}{c}0.056^{* * *} \\
(0.016)\end{array}$ \\
\hline Region and Decade FE & $\mathrm{NO}$ & YES & YES & NO & YES & YES \\
\hline$\Delta$ after Successful Coup $\left(\beta_{1}+\beta_{3}\right)$ & 1.191 & 0.270 & 0.256 & 0.122 & 0.094 & 0.095 \\
\hline Test: Successful Coup not 0 & $0.24(0.624)$ & $0.34(0.561)$ & $0.54(0.466)$ & $1.16(0.286)$ & $1.94(0.171)$ & $2.11(0.154)$ \\
\hline Observations & 180 & 131 & 131 & 194 & 133 & 133 \\
\hline R-squared & 0.031 & 0.510 & .605 & 0.018 & 0.890 & 0.898 \\
\hline
\end{tabular}

Notes: * significance at the $10 \%$ level, $* *$ at the $5 \%$ level, $* * *$ at the $1 \%$ level. Standard errors are clustered by country and reported in parenthesis. Military Exp / GDP is measured between 0 and 100, Military Exp and GDP are in millions of US\$ (2000), GDP per capita is in US\$ (2000), population and the size of the military are in millions. Instability is measured in thousands. Test is an F-test, with the F-statistic followed by the p-value in parenthesis. 
Table 14: Comparing the Treatment and Control Groups

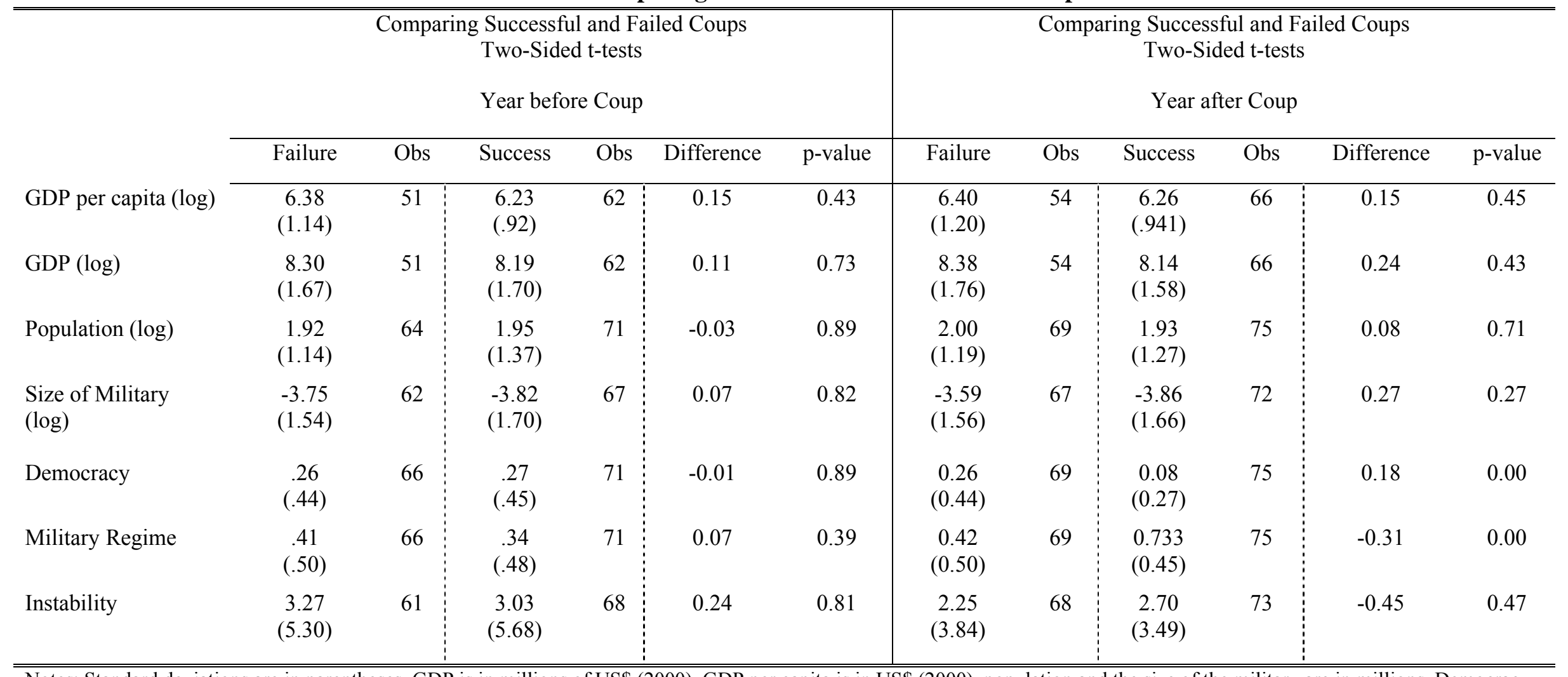

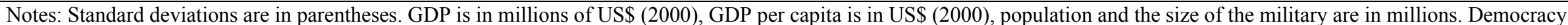

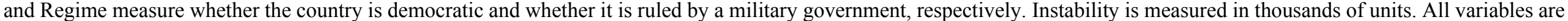
dated the year before the coup. 


\section{Table 15: Summary Statistics}

for Panel Analysis

\begin{tabular}{lccc}
\hline \hline & Mean & Std. Deviation & Observations \\
\cline { 2 - 4 } Coup (5 years) & 0.18 & 0.38 & 885 \\
Military Expenditures / GDP (Total=100) & 4.66 & 6.78 & 742 \\
Military Expenditures (Millions, 2000\$) & 5,805 & 28,940 & 816 \\
GDP per capita (2000\$) & 5,013 & 7526 & 754 \\
GDP (Millions, 2000\$) & 140,799 & 605,254 & 755 \\
Population (in Millions) & 31 & 1.52 & 867 \\
Size of Military (in Millions) & 0.16 & 0.43 & 867 \\
Democracy & 0.38 & 0.48 & 1,056 \\
Military Regime & 0.22 & 0.42 & 1,056 \\
Instability & 3,217 & 7,170 & 851 \\
\hline
\end{tabular}

Notes: Coup (5 years) is equal to 1 if there was at least one coup attempt (successful or failed) in the 5 year period, and 0 otherwise. The periods are 1965-1969, 1970-1974, 1975-1979, 1980-1984, 1985-1989, 1990-1994, 1995-1999. Democracy is a binary variable that equals 1 if the country was democratic and 0 othewise; Military Regime equals 1 if the government was in the hands of the military, 0 otherwise; Instability measure political instability and is from Banks (2001). All variables are dated the year before the a five year period starts. 
Table 16: Military Spending and Coups (5 years)

\begin{tabular}{|c|c|c|c|c|c|c|}
\hline & (1) & $(2)$ & (3) & (4) & (5) & (6) \\
\hline & $\begin{array}{c}\text { Coup }_{t} \\
\text { (5 years) }\end{array}$ & $\begin{array}{c}\text { Coup }_{t} \\
\text { (5 years) }\end{array}$ & $\begin{array}{c}\text { Coupt }_{t} \\
\text { (5 years) }\end{array}$ & $\begin{array}{c}\text { Coup }_{\mathrm{t}} \\
\text { (5 years) }\end{array}$ & $\begin{array}{c}\text { Coup }_{\mathrm{t}} \\
\text { (5 years) }\end{array}$ & $\begin{array}{c}\text { Coup }_{t} \\
\text { (5 years) }\end{array}$ \\
\hline & \multicolumn{2}{|c|}{ Cross-Country } & \multicolumn{2}{|c|}{ Fixed Effects } & \multicolumn{2}{|c|}{ Conditional Logit } \\
\hline Military Exp / GDP ${ }_{t-1}$ & $\begin{array}{c}-0.005^{* *} \\
(0.002)\end{array}$ & $\begin{array}{l}-0.002 \\
(0.002)\end{array}$ & $\begin{array}{c}-0.015^{* * *} \\
(0.004)\end{array}$ & $\begin{array}{c}-0.015 * * * \\
(0.004)\end{array}$ & $\begin{array}{l}-0.143 * \\
(0.081)\end{array}$ & $\begin{array}{c}-0.148 * \\
(0.085)\end{array}$ \\
\hline GDP per capita ${ }_{\mathrm{t}-1}(\log )$ & & $\begin{array}{c}-0.060 * * * \\
(0.015)\end{array}$ & $\begin{array}{c}0.001 \\
(0.079)\end{array}$ & & & $\begin{array}{l}-0.789 \\
(1.123)\end{array}$ \\
\hline $\mathrm{GDP}_{\mathrm{t}-1}(\log )$ & $\begin{array}{c}-0.072 * * * \\
(0.016)\end{array}$ & & & $\begin{array}{l}-0.010 \\
(0.077)\end{array}$ & $\begin{array}{l}-0.574 \\
(1.201)\end{array}$ & \\
\hline Pop $_{t-1}(\log )$ & $\begin{array}{c}0.034 \\
(0.025)\end{array}$ & & & $\begin{array}{c}-0.059 \\
(0.157)\end{array}$ & $\begin{array}{c}1.919 \\
(2.771)\end{array}$ & \\
\hline Size of Military t-1 $(\log )$ & $\begin{array}{c}0.006 \\
(0.025)\end{array}$ & $\begin{array}{l}-0.025 * * \\
(0.011)\end{array}$ & $\begin{array}{c}0.032 \\
(0.044)\end{array}$ & $\begin{array}{c}0.039 \\
(0.051)\end{array}$ & $\begin{array}{c}0.478 \\
(0.501)\end{array}$ & $\begin{array}{c}0.516 \\
(0.414)\end{array}$ \\
\hline Democracy $_{\mathrm{t}-1}$ & $\begin{array}{l}0.066 * \\
(0.040)\end{array}$ & $\begin{array}{c}0.057 \\
(0.040)\end{array}$ & $\begin{array}{c}-0.106 \\
(0.094)\end{array}$ & $\begin{array}{l}-0.106 \\
(0.094)\end{array}$ & $\begin{array}{c}0.136 \\
(0.730)\end{array}$ & $\begin{array}{c}0.098 \\
(0.713)\end{array}$ \\
\hline Military Regime $_{\mathrm{t}-1}$ & $\begin{array}{c}0.135 * * * \\
(0.048)\end{array}$ & $\begin{array}{c}0.137 * * * \\
(0.048)\end{array}$ & $\begin{array}{l}-0.105 \\
(0.092)\end{array}$ & $\begin{array}{l}-0.106 \\
(0.092)\end{array}$ & $\begin{array}{l}-0.181 \\
(0.595)\end{array}$ & $\begin{array}{l}-0.238 \\
(0.649)\end{array}$ \\
\hline Instability $_{\mathrm{t}-1}$ & $\begin{array}{l}0.006 * \\
(0.003)\end{array}$ & $\begin{array}{l}0.005 * \\
(0.003)\end{array}$ & $\begin{array}{c}0.006 * * \\
(0.002)\end{array}$ & $\begin{array}{c}0.006 * * \\
(0.002)\end{array}$ & $\begin{array}{c}0.108 \\
(0.040)\end{array}$ & $\begin{array}{c}0.105 \\
(0.038)\end{array}$ \\
\hline Year FE & $\mathrm{Y}$ & $\mathrm{Y}$ & $\mathrm{Y}$ & $\mathrm{Y}$ & $\mathrm{Y}$ & $\mathrm{Y}$ \\
\hline Country FE & $\mathrm{N}$ & $\mathrm{N}$ & $\mathrm{Y}$ & $\mathrm{Y}$ & $\mathrm{Y}$ & $\mathrm{Y}$ \\
\hline Observations & 681 & 681 & 681 & 681 & 302 & 302 \\
\hline
\end{tabular}

Notes: *significance at the $10 \%$ level, $* *$ at the $5 \%$ level, $* * *$ at the $1 \%$ level. Standard errors in parentheses. All standard errors are clustered at the country level, conditional logit errors are bootstrapped. Coup ( 5 years) is equal to 1 if there was at least one coup in the 5 year period, and 0 otherwise. The periods are 1965-1969, 1970-1974, 1975-1979, 1980-1984, 1985-1989, 1990-1994, $1995-1999$. GDP is in millions of US\$ (2000), GDP per capita is in US\$ (2000), population and the size of the military are in millions. Democracy equals 1 if the country was democratic and 0 othewise; Military Regime equals 1 if the government was in the hands of the military, 0 otherwise. Instability is measured in thousands of units. All variables are dated the year before the a five year period starts. 
Table 17: Military Spending and Coups By Political Regimes

\begin{tabular}{|c|c|c|c|c|}
\hline & (1) & $(2)$ & (3) & (4) \\
\hline & $\begin{array}{c}\text { Coup }_{t} \\
\text { (5 years) }\end{array}$ & $\begin{array}{c}\text { Coupt }_{t} \\
\text { (5 years) }\end{array}$ & $\begin{array}{c}\text { Coup }_{t} \\
\text { (5 years) }\end{array}$ & $\begin{array}{c}\text { Coupt }_{t} \\
\text { (5 years) }\end{array}$ \\
\hline & \multicolumn{2}{|c|}{ Fixed Effects } & \multicolumn{2}{|c|}{ Conditional Logit } \\
\hline Military Exp / GDP ${ }_{t-1}$ & $\begin{array}{c}-0.016 * * * \\
(0.004)\end{array}$ & $\begin{array}{c}-0.016 * * * \\
(0.004)\end{array}$ & $\begin{array}{c}-0.166^{*} \\
(0.092)\end{array}$ & $\begin{array}{l}-0.170 \\
(0.108)\end{array}$ \\
\hline Military Exp / GDP ${ }_{t-1} \mathrm{x}$ & 0.007 & 0.008 & 0.112 & 0.098 \\
\hline Democracy & $(0.009)$ & $(0.009)$ & $(0.255)$ & $(0.277)$ \\
\hline GDP per capita t-1 $_{(}(\log )$ & & $\begin{array}{c}-0.0003 \\
(0.079)\end{array}$ & & $\begin{array}{l}-0.812 \\
(1.194)\end{array}$ \\
\hline $\mathrm{GDP}_{\mathrm{t}-1}(\log )$ & $\begin{array}{l}-0.010 \\
(0.077)\end{array}$ & & $\begin{array}{l}-0.572 \\
(1.184)\end{array}$ & \\
\hline Pop $_{t-1}(\log )$ & $\begin{array}{c}-0.052 \\
(0.156)\end{array}$ & & $\begin{array}{c}3.128 \\
(2.951)\end{array}$ & \\
\hline Size of Military t-1 (log) & $\begin{array}{l}-0.108 \\
(0.093)\end{array}$ & $\begin{array}{c}0.028 \\
(0.044)\end{array}$ & $\begin{array}{c}0.415 \\
(0.613)\end{array}$ & $\begin{array}{c}0.475 \\
(0.471)\end{array}$ \\
\hline Democracy t-1 & $\begin{array}{c}-0.131 \\
(0.104)\end{array}$ & $\begin{array}{l}-0.133 \\
(0.104)\end{array}$ & $\begin{array}{l}-0.181 \\
(0.939)\end{array}$ & $\begin{array}{c}-0.174 \\
(1.031)\end{array}$ \\
\hline Military Regime $_{\mathrm{t}-1}$ & $\begin{array}{c}-0.108 \\
(0.093)\end{array}$ & $\begin{array}{c}-0.107 \\
(0.093)\end{array}$ & $\begin{array}{l}-0.138 \\
(0.603)\end{array}$ & $\begin{array}{c}-0.204 \\
(0.598)\end{array}$ \\
\hline Instability ${ }_{t-1}$ & $\begin{array}{c}0.006 * * \\
(0.003)\end{array}$ & $\begin{array}{c}0.006 * * \\
(0.003)\end{array}$ & $\begin{array}{c}0.109 * * * \\
(0.028)\end{array}$ & $\begin{array}{c}0.106^{* * *} \\
(0.036)\end{array}$ \\
\hline Year FE & $\mathrm{Y}$ & $\mathrm{Y}$ & $\mathrm{Y}$ & $\mathrm{Y}$ \\
\hline Country FE & $\mathrm{Y}$ & $\mathrm{Y}$ & $\mathrm{Y}$ & $\mathrm{Y}$ \\
\hline Observations & 681 & 681 & 302 & 302 \\
\hline $\begin{array}{l}\text { Notes: *significance at the } \\
\text { parentheses. All standard } \\
\text { bootstrapped. Coup ( } 5 \text { year } \\
\text { otherwise. The periods are } \\
\text { 1995-1999. GDP is in milli } \\
\text { size of the military are in m } \\
\text { Military Regime equals } 1 \text { if }\end{array}$ & $\begin{array}{l}\text { level, } * * \text { at } t \\
\text { are clustere } \\
\text { qual to } 1 \text { if tl } \\
\text {-1969, 1970- } \\
\text { US\$ (2000), } \\
\text { Democracy } \\
\text { vernment wa }\end{array}$ & $\begin{array}{l}\text { o level, *** } \\
\text { the country } \\
\text { was at least } \\
1975-1979 \\
\text { per capita } \\
\text { s } 1 \text { if the co } \\
\text { he hands of }\end{array}$ & $\begin{array}{l}\text { e } 1 \% \text { level. } \\
\text { l, condition } \\
\text { bup in the } 5 \\
-1984,1985 \\
\text { JS\$ (2000), } \\
\text { was democra } \\
\text { litary, } 0 \text { othe }\end{array}$ & $\begin{array}{l}\text { dard errors in } \\
\text { git errors are } \\
\text { period, and } 0 \\
99,1990-1994 \text {, } \\
\text { llation and the } \\
\text { nd } 0 \text { othewise; } \\
\text { e. Instability is }\end{array}$ \\
\hline
\end{tabular}




\section{ONLINE APPENDIX}

Table A1: Difference in Differences: Including Consecutive Coups

(One Year Before and After)

\begin{tabular}{|c|c|c|c|c|}
\hline & (1) & (2) & (3) & (4) \\
\hline & Military Exp/GDP & Military Exp/GDP & Military Exp (log) & Military Exp (log) \\
\hline Post-Coup dummy $\left(\beta_{1}\right)$ & $\begin{array}{c}-0.300 \\
(0.258)\end{array}$ & $\begin{array}{l}-0.220 \\
(0.259)\end{array}$ & $\begin{array}{l}-0.070 \\
(0.095)\end{array}$ & $\begin{array}{c}-0.090 \\
(0.089)\end{array}$ \\
\hline Success dummy $\left(\beta_{2}\right)$ & $\begin{array}{l}-0.455 \\
(0.429)\end{array}$ & $\begin{array}{l}-0.484 \\
(0.400)\end{array}$ & $\begin{array}{l}-0.128 \\
(0.122)\end{array}$ & $\begin{array}{l}-0.116 \\
(0.111)\end{array}$ \\
\hline $\begin{array}{l}\text { Post_Coup x Success } \\
\text { Dummies }\left(\beta_{3}\right)\end{array}$ & $\begin{array}{l}0.774 * \\
(0.390)\end{array}$ & $\begin{array}{l}0.746 * \\
(0.398)\end{array}$ & $\begin{array}{l}0.231 * \\
(0.120)\end{array}$ & $\begin{array}{c}0.237 * * \\
(0.118)\end{array}$ \\
\hline GDP per capita (log) & $\begin{array}{c}-1.105^{* * *} \\
(0.150)\end{array}$ & & $\begin{array}{c}0.280 * * * \\
(0.077)\end{array}$ & \\
\hline GDP $(\log )$ & & $\begin{array}{c}-1.596 * * * \\
(0.413)\end{array}$ & & $\begin{array}{c}0.403 * * * \\
(0.073)\end{array}$ \\
\hline Population (log) & & $\begin{array}{l}-0.156 \\
(0.590)\end{array}$ & & $\begin{array}{c}0.023 \\
(0.117)\end{array}$ \\
\hline Size of Military t-1 $(\log )$ & $\begin{array}{c}0.481 * * * \\
(0.150)\end{array}$ & $\begin{array}{l}1.717 * * * \\
(0.465)\end{array}$ & $\begin{array}{c}0.967 * * * \\
(0.053)\end{array}$ & $\begin{array}{l}0.665 * * * \\
(0.101)\end{array}$ \\
\hline Democracy $t-1$ & $\begin{array}{l}-1.609 * \\
(0.936)\end{array}$ & $\begin{array}{l}-1.115 \\
(0.891)\end{array}$ & $\begin{array}{c}0.066 \\
(0.190)\end{array}$ & $\begin{array}{l}-0.050 \\
(0.177)\end{array}$ \\
\hline Military Regime ${ }_{t-1}$ & $\begin{array}{l}-0.777 \\
(0.685)\end{array}$ & $\begin{array}{l}-0.786 \\
(0.646)\end{array}$ & $\begin{array}{l}-0.030 \\
(0.136)\end{array}$ & $\begin{array}{c}-0.026 \\
(0.138)\end{array}$ \\
\hline Instability $\mathrm{t}-1$ & $\begin{array}{l}-0.010 \\
(0.030)\end{array}$ & $\begin{array}{c}0.006 \\
(0.031)\end{array}$ & $\begin{array}{c}0.009 \\
(0.009)\end{array}$ & $\begin{array}{c}0.005 \\
(0.008)\end{array}$ \\
\hline Years in Event & $\begin{array}{l}-0.351 \\
(0.394)\end{array}$ & $\begin{array}{l}-0.422 \\
(0.310)\end{array}$ & $\begin{array}{l}-0.174 \\
(0.093)\end{array}$ & $\begin{array}{l}-0.155 \\
(0.095)\end{array}$ \\
\hline Region and Decade FE & Yes & Yes & Yes & Yes \\
\hline Observations & 223 & 223 & 225 & 225 \\
\hline R-squared & 0.354 & 0.434 & 0.888 & 0.901 \\
\hline
\end{tabular}

Notes: In this table we include coups that happen in consecutive years, we group them into 'events' and the year before the first coup is the pre-coup year, while the year after the last coup is the post-coup year. *significance at the $10 \%$ level, ** at the $5 \%$ level, $* * *$ at the $1 \%$ level. Standard errors are clustered by country and reported in parenthesis. 
Table A2: Difference in Differences (Three Years Before and After) and Regional Time Trends

\begin{tabular}{|c|c|c|c|c|c|c|c|c|}
\hline & $\begin{array}{c}(1) \\
\text { Military } \\
\text { Exp/GDP }\end{array}$ & $\begin{array}{c}(2) \\
\text { Military } \\
\text { Exp/GDP }\end{array}$ & $\begin{array}{c}(3) \\
\text { Military Exp } \\
(\log )\end{array}$ & $\begin{array}{c}(4) \\
\text { Military Exp } \\
(\log )\end{array}$ & $\begin{array}{c}(5) \\
\text { Military } \\
\text { Exp/GDP }\end{array}$ & $\begin{array}{c}(6) \\
\text { Military } \\
\text { Exp/GDP }\end{array}$ & $\begin{array}{c}(7) \\
\text { Military Exp } \\
(\log )\end{array}$ & $\begin{array}{c}(8) \\
\text { Military Exp } \\
(\log )\end{array}$ \\
\hline Post-Coup dummy $\left(\beta_{1}\right)$ & $\begin{array}{l}-0.342 \\
(0.284)\end{array}$ & $\begin{array}{l}-0.291 \\
(0.313)\end{array}$ & $\begin{array}{l}-0.038 \\
(0.122)\end{array}$ & $\begin{array}{l}-0.108 \\
(0.097)\end{array}$ & $\begin{array}{l}-0.394 \\
(0.768)\end{array}$ & $\begin{array}{l}-0.575 \\
(0.676)\end{array}$ & $\begin{array}{l}-0.376^{*} \\
(0.194)\end{array}$ & $\begin{array}{l}-0.229 \\
(0.155)\end{array}$ \\
\hline Success dummy $\left(\beta_{2}\right)$ & $\begin{array}{l}-0.372 \\
(0.535)\end{array}$ & $\begin{array}{l}-0.374 \\
(0.535)\end{array}$ & $\begin{array}{l}-0.092 \\
(0.189)\end{array}$ & $\begin{array}{l}-0.080 \\
(0.151)\end{array}$ & $\begin{array}{l}-0.586 \\
(0.529)\end{array}$ & $\begin{array}{l}-0.497 \\
(0.524)\end{array}$ & $\begin{array}{l}-0.031 \\
(0.221)\end{array}$ & $\begin{array}{l}-0.085 \\
(0.155)\end{array}$ \\
\hline $\begin{array}{l}\text { Post_Coup x Success } \\
\text { Dummies }\left(\beta_{3}\right)\end{array}$ & $\begin{array}{l}1.024 * \\
(0.564)\end{array}$ & $\begin{array}{l}0.995 * \\
(0.582)\end{array}$ & $\begin{array}{c}0.312 \\
(0.192)\end{array}$ & $\begin{array}{c}0.344 * * \\
(0.165)\end{array}$ & $\begin{array}{l}1.249 * * \\
(0.539)\end{array}$ & $\begin{array}{l}1.077 * \\
(0.541)\end{array}$ & $\begin{array}{c}0.262 \\
(0.196)\end{array}$ & $\begin{array}{l}0.342 * \\
(0.173)\end{array}$ \\
\hline GDP per capita (log) & $\begin{array}{c}-0.759 * * \\
(0.326)\end{array}$ & & $\begin{array}{c}0.356 * * * \\
(0.096)\end{array}$ & & $\begin{array}{l}-0.278 \\
(0.231)\end{array}$ & & $\begin{array}{c}0.333 * * * \\
(0.088)\end{array}$ & \\
\hline GDP $(\log )$ & & $\begin{array}{c}-0.884 * * \\
(0.379)\end{array}$ & & $\begin{array}{l}0.576^{* * * *} \\
(0.085)\end{array}$ & & $\begin{array}{c}-0.685^{* *} \\
(0.338)\end{array}$ & & $\begin{array}{c}0.595 * * * \\
(0.078)\end{array}$ \\
\hline Population (log) & & $\begin{array}{c}0.449 \\
(0.450)\end{array}$ & & $\begin{array}{l}0.209 * \\
(0.114)\end{array}$ & & $\begin{array}{l}-0.288 \\
(0.405)\end{array}$ & & $\begin{array}{c}0.026 \\
(0.117)\end{array}$ \\
\hline Size of Military $\mathrm{t}-1(\log )$ & $\begin{array}{l}0.347 * \\
(0.184)\end{array}$ & $\begin{array}{c}0.713 \\
(0.426)\end{array}$ & $\begin{array}{c}0.980 * * * \\
(0.075)\end{array}$ & $\begin{array}{l}0.325 * * * \\
(0.103)\end{array}$ & $\begin{array}{l}0.483 * * * \\
(0.178)\end{array}$ & $\begin{array}{l}1.221 * * \\
(0.510)\end{array}$ & $\begin{array}{l}0.926 * * * \\
(0.048)\end{array}$ & $\begin{array}{l}0.463 * * * \\
(0.100)\end{array}$ \\
\hline Democracy $t-1$ & $\begin{array}{c}0.132 \\
(0.494)\end{array}$ & $\begin{array}{c}0.162 \\
(0.462)\end{array}$ & $\begin{array}{c}0.173 \\
(0.140)\end{array}$ & $\begin{array}{c}0.106 \\
(0.126)\end{array}$ & $\begin{array}{l}-0.248 \\
(0.764)\end{array}$ & $\begin{array}{c}0.012 \\
(0.587)\end{array}$ & $\begin{array}{c}0.219 \\
(0.154)\end{array}$ & $\begin{array}{c}0.019 \\
(0.136)\end{array}$ \\
\hline Military Regime $_{\mathrm{t}-1}$ & $\begin{array}{l}-0.234 \\
(0.426)\end{array}$ & $\begin{array}{l}-0.260 \\
(0.439)\end{array}$ & $\begin{array}{l}-0.064 \\
(0.186)\end{array}$ & $\begin{array}{l}-0.029 \\
(0.149)\end{array}$ & $\begin{array}{l}-0.496 \\
(0.597)\end{array}$ & $\begin{array}{l}-0.384 \\
(0.553)\end{array}$ & $\begin{array}{c}0.022 \\
(0.223)\end{array}$ & $\begin{array}{l}-0.055 \\
(0.164)\end{array}$ \\
\hline Instability $\mathrm{t}-1$ & $\begin{array}{l}-0.032 \\
(0.028)\end{array}$ & $\begin{array}{l}-0.035 \\
(0.025)\end{array}$ & $\begin{array}{l}-0.006 \\
(0.009)\end{array}$ & $\begin{array}{l}-0.001 \\
(0.008)\end{array}$ & $\begin{array}{l}-0.031 \\
(0.024)\end{array}$ & $\begin{array}{l}-0.039 * \\
(0.023)\end{array}$ & $\begin{array}{l}-0.009 \\
(0.010)\end{array}$ & $\begin{array}{l}-0.003 \\
(0.008)\end{array}$ \\
\hline $\begin{array}{l}\text { Regional Time Trends and } \\
\text { Decade FE }\end{array}$ & $\mathrm{NO}$ & $\mathrm{NO}$ & NO & NO & YES & YES & YES & YES \\
\hline Region and Decade FE & YES & YES & YES & YES & NO & NO & NO & NO \\
\hline Observations & 288 & 288 & 293 & 293 & 288 & 288 & 293 & 293 \\
\hline R-squared & 0.264 & 0.271 & 0.888 & 0.922 & 0.201 & 0.247 & 0.887 & 0.915 \\
\hline
\end{tabular}

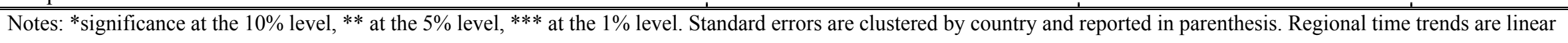


Table A3: Comparing the Treatment and Control Groups

\begin{tabular}{|c|c|c|c|c|c|c|c|c|c|c|c|c|}
\hline & \multicolumn{6}{|c|}{$\begin{array}{c}\text { Comparing Successful and Failed Coups } \\
\text { Two-Sided t-tests } \\
\text { Year before Coup }\end{array}$} & \multicolumn{6}{|c|}{$\begin{array}{c}\text { Comparing Successful and Failed Coups } \\
\text { Two-Sided t-tests } \\
3 \text { Years after Coup }\end{array}$} \\
\hline & Failure & Obs & Success & Obs & Difference & p-value & Failure & Obs & Success & Obs & Difference & p-value \\
\hline GDP per capita (log) & $\begin{array}{c}6.38 \\
(1.14)\end{array}$ & 51 & $\begin{array}{l}6.23 \\
(.92)\end{array}$ & 62 & 0.15 & 0.43 & $\begin{array}{c}6.47 \\
(1.19)\end{array}$ & 52 & $\begin{array}{c}6.25 \\
(0.94)\end{array}$ & 66 & 0.22 & 0.27 \\
\hline GDP (log) & $\begin{array}{c}8.30 \\
(1.67)\end{array}$ & 51 & $\begin{array}{c}8.19 \\
(1.70)\end{array}$ & 62 & 0.11 & 0.73 & $\begin{array}{c}8.56 \\
(1.78)\end{array}$ & 52 & $\begin{array}{c}8.22 \\
(1.58)\end{array}$ & 66 & 0.34 & 0.31 \\
\hline Population (log) & $\begin{array}{c}1.92 \\
(1.14)\end{array}$ & 64 & $\begin{array}{c}1.95 \\
(1.37)\end{array}$ & 71 & -0.03 & 0.89 & $\begin{array}{c}2.09 \\
(1.17)\end{array}$ & 65 & $\begin{array}{c}1.97 \\
(1.29)\end{array}$ & 74 & 0.12 & 0.58 \\
\hline Size of Military $(\log )$ & $\begin{array}{l}-3.75 \\
(1.54)\end{array}$ & 62 & $\begin{array}{l}-3.82 \\
(1.70)\end{array}$ & 67 & 0.07 & 0.82 & $\begin{array}{l}-3.52 \\
(1.53)\end{array}$ & 62 & $\begin{array}{l}-3.75 \\
(1.66)\end{array}$ & 70 & 0.23 & 0.20 \\
\hline Democracy & $\begin{array}{c}.26 \\
(.44)\end{array}$ & 66 & $\begin{array}{c}.27 \\
(.45)\end{array}$ & 71 & -0.01 & 0.89 & $\begin{array}{c}0.25 \\
(0.43)\end{array}$ & 65 & $\begin{array}{c}0.12 \\
(0.33)\end{array}$ & 75 & 0.13 & 0.05 \\
\hline Military Regime & $\begin{array}{c}.41 \\
(.50)\end{array}$ & 66 & $\begin{array}{c}.34 \\
(.48)\end{array}$ & 71 & 0.07 & 0.39 & $\begin{array}{c}0.45 \\
(0.50)\end{array}$ & 65 & $\begin{array}{c}0.69 \\
(0.46)\end{array}$ & 75 & -0.25 & 0.00 \\
\hline Instability & $\begin{array}{c}3.27 \\
(5.30)\end{array}$ & 61 & $\begin{array}{c}3.03 \\
(5.68)\end{array}$ & 68 & 0.24 & 0.81 & $\begin{array}{c}2.13 \\
(3.10)\end{array}$ & 65 & $\begin{array}{c}2.91 \\
(5.06)\end{array}$ & 75 & -0.78 & 0.28 \\
\hline
\end{tabular}

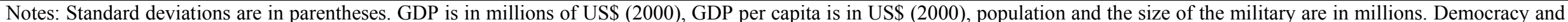

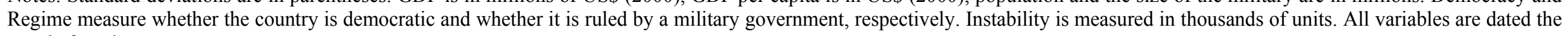
year before the coup. 


\section{Online Data Appendix}

The main units of observation are (country, year) pairs.

Coup - This is a binary variable that is equal to 1 if at least one coup occurred, and 0 otherwise. It is taken from the dataset by Belkin and Schofer (2003), where a coup is defined as an attempt to remove the 'regime' by a 'small military coalition.'

Coup Success - This is a binary variable that equals 1 if at least one coup was successful in the given (country, year). It is constructed by using data from Banks (2001) and Powell and Thyne (2011) to determine whether a coup was successful or not. These databases agree in all but a small number of cases, which we confirmed by looking at online news sources.

Military Spending - This variable is from the U.S. Arms Control and Disarmament Agency. We compiled a number of annual reports with data on military spending, the size of the military, and some country characteristics. Our measure includes all military expenditures in the (country, year), including both operational expenses (e.g. salaries) and arms purchases. The U.S. Arms Control and Disarmament Agency reports this data in two ways: in millions of US dollars (2000) and as a fraction of GDP.

Size of the Military - This variable is from the U.S. Arms Control and Disarmament Agency. It is measured in millions.

GDP, Population - The GDP and population variables are from the World Bank Development Indicators (2009). GDP is measured in millions of US dollars (2000). Population is measured in millions. 
Democracy - This variable is the 'democracy' variable from Cheibub, Gandhi and Vreeland (2010) and it equals 1 if the regime is a democracy and 0 if it is a dictatorship. The Cheibub, Gandhi and Vreeland (2010) dataset is rooted in the Alvarez et al. (1996) and Przeworski et al. (2000) datasets and shares with them the classification of regimes into just two categories democracy and dictatorship.

Military Regime - This variable is constructed from the 'regime' variable in Cheibub, Gandhi and Vreeland (2010). The regime variable can be equal to parliamentary democracy, semipresidential democracy, presidential democracy, monarchic dictatorship, military dictatorship, and civilian dictatorship. Our variable is equal to 1 if 'regime' equals 'military dictatorship', and 0 otherwise.

Instability - We use the variable S18F2 'Weighted Conflict Index' from Banks (2001), which is the same used by Powell (2010). This variable is calculated by giving weights to scores on assassinations, general strikes, guerrilla warfare, government crises, purges, riots, revolutions, and anti-government demonstrations. This variable takes very large numerical values, and so in the regressions we measure it in thousands.

Casualties - This data is from the Center for Systemic Peace database by Marshall and Marshall (2010), complemented with data we collected from the New York Times Archive. We coded it as a binary variable; 0 if no deaths were reported, 1 if at least one death was reported.

In the panel section, we use the following variable: 
Coup (5 years) - Equals 1 if there was at least one coup in the 5 year period, 0 otherwise. 